\title{
RECENT SEDIMENTOLOGICAL INTERPRETATIONS IN THE AVALON TERRANE OF THE BOSTON BASIN, MASSACHUSETTS
}

\author{
Anthony D. Socci and Geoffrey W. Smith \\ Department of Geological Sciences \\ Ohio University \\ Athens, Oh10 45701
}

Date Received April 25, 1986

Date Accepted November 12, 1986

\begin{abstract}
The depositional history of the Boston Basin remains somewhat enfomatic and controversial despite nearly over a century of research. Resolution of the basin's geologic history has remalned formidable and complex due, in part, to attempts to work within the existing stratigraphy which of ten carried with it historic interpretations, many of which went uncontested. More importantly however, our knowledge of depositional systems and mechanisms has increased significantly over this span of time. Reinterpretations in Iight of these advances were not only inevitable but neccessary. As a consequence of the circumstances described above, our reinvestigation into the depositional history of the Boston Basin succession, principally the Boston Bay Group, has centered on recognizing, measuring, and coding a suite of facies whose textures in many instances can be closely inked to specific depositional mechanisms responstble for the emplacement of the facies in question. From this factes analysis a prelintnary depositional model for the Boston Basin has begun to emerge.

It appears that the Boston Basin orfginated as a rifted successor, or arc-related basin e1ther just prior to the closure of the Cadomian Ocean or during the opening of Iapetus. The early history of the basin is marked by the presence of a suite of bimodal volcanics in the form of water-lain tuffs, dikes, sills, and flows, and coarse debris flows. Geochemical markers suggest that the basin was in contact with the open ocean very early in its history.

The next stage in the evolution of the Boston Basin was marked by the development of a rapid1y prograding submarine slope/fan succession. The slope/fan setting appears to have been characterized by the deposition of ice frontal and/or ice-rafted diamictons which periodically overloaded the slope initiating sediment gravity flows which reworked and redistributed sediment downslope. During periods of more equable climate and/or tectonic quiescence, blankets of fine sand and mud were deposited. There is no evidence of a shelf or sheif-type deposits during this time.

The last stage in the evolution of the basin was the appearance of shelf sediments such as quartz and calcareous sands, and muds with abundant organic matter and shelled organisms. There 1s also evidence for climatic warming which is suggested to have been brought about by a tectontcally-forced rise in eustatic sea-level.
\end{abstract}

L'histoire sédimentaire du Bassin de Boston soulève encore quelques enigmes et controverses et, cela, après près d'un siecle de travaux. Dans une certaine mesure, la résolution de 1 'bistołre géologique du bassin est demeurée formidable et complexe par suite des tentatives de travaliler au sein de la stratigraphie actuelle qui, elle, comportait souvent des interpretations historiques rarement mises en doute. Or. plus important est le bond en avant saisissant qu'a fait notre connalssance des systèmes et mécanismes de dépôt durant cette pérłode. I1 devint done non seulement inévitable, mais bien nécessaire de reconsiderer les conceptions traditionnelles a la lumiere de ces acquis. Pour ce faire, notre réxamen de l'histolre sédimentalre de la succession du Bassin de Boston, et surtout du Groupe de Boston Bay, s'est axé sur la reconnalssance, la mesure et le codage d'une suite de facies dont les textures sont souvent reliées de facon intime aux mécanismes de depôt distincts responsables de la mise en place desdits faciès. Cette analyse faćlologique commence a engendrer un modele préliminaire du dépôt dans le Bassin de Boston.

I1 semble que le Bassin de Boston ait débuté sous forme d'un rift successeur ou d'un bassin allie à un are solt juste avant le serrage de I'Océan Cadomien, solt lors de I'ouverture de L'Iapetus. L'histoire du bassin est d'abord marqué par la présence d'une sulte de volcanites bimodales sous formes de tufs aquatiques, dykes, filons-couches, coulées et coulées de débris. Les marqueurs géochimiques suggèrent que le bassin etalt ouvert sur le large dès 1 'amorce de son histoire.

Le stade sufvant dans 1 'évolution du Bassin de Boston fut marqué par le développement d'une séquence de pente et cône sous-marins a progradation rapide. L'environnement de pente et cône semble avolr été caractérisé par le dépôt de diamictons glaciaires frontaux et/ou supraglaciaires qui ont surchargé perlodiquement la pente, declenchant atnsi des ecoulements gravitajres qui ont repris les sediments et les ont redistribue en bas de pente. Les periodes de climat plus uniforme et/ou de stase tectonique donnerent lieu a des epandages de sable fin et de boue. on ne trouve pas trace d'une plate-forme ou de depôts typiques d'une plate-forme lors de cette période. La dernière phase évolutive du bassin correspond a l'apparition de sediments de plate-forme tels que des sables quartzeux et calcaires ainsi que des boues riches en mattere organique et en organismes coquililers. Certains indices témoignent d'un rechauffement climatique que 1 on croit dû a une elevation eustatique du niveau marin en reponse aux sollicitations de la tectonique.

[Traduit par 1e journa1]

\section{INTRODUCTION}

The depositional setting and geologic history of the Boston Basin (F1g. 1) succession has remained in dispute for over a century. The lack of resolu- tion and lack of agreement on the depositional history of the basin can likely be attributed to 1) paucity of continuous outcrop; 2) scarcity of subsurface 1ithologic information with the exception of the data compiled by Billings, his 


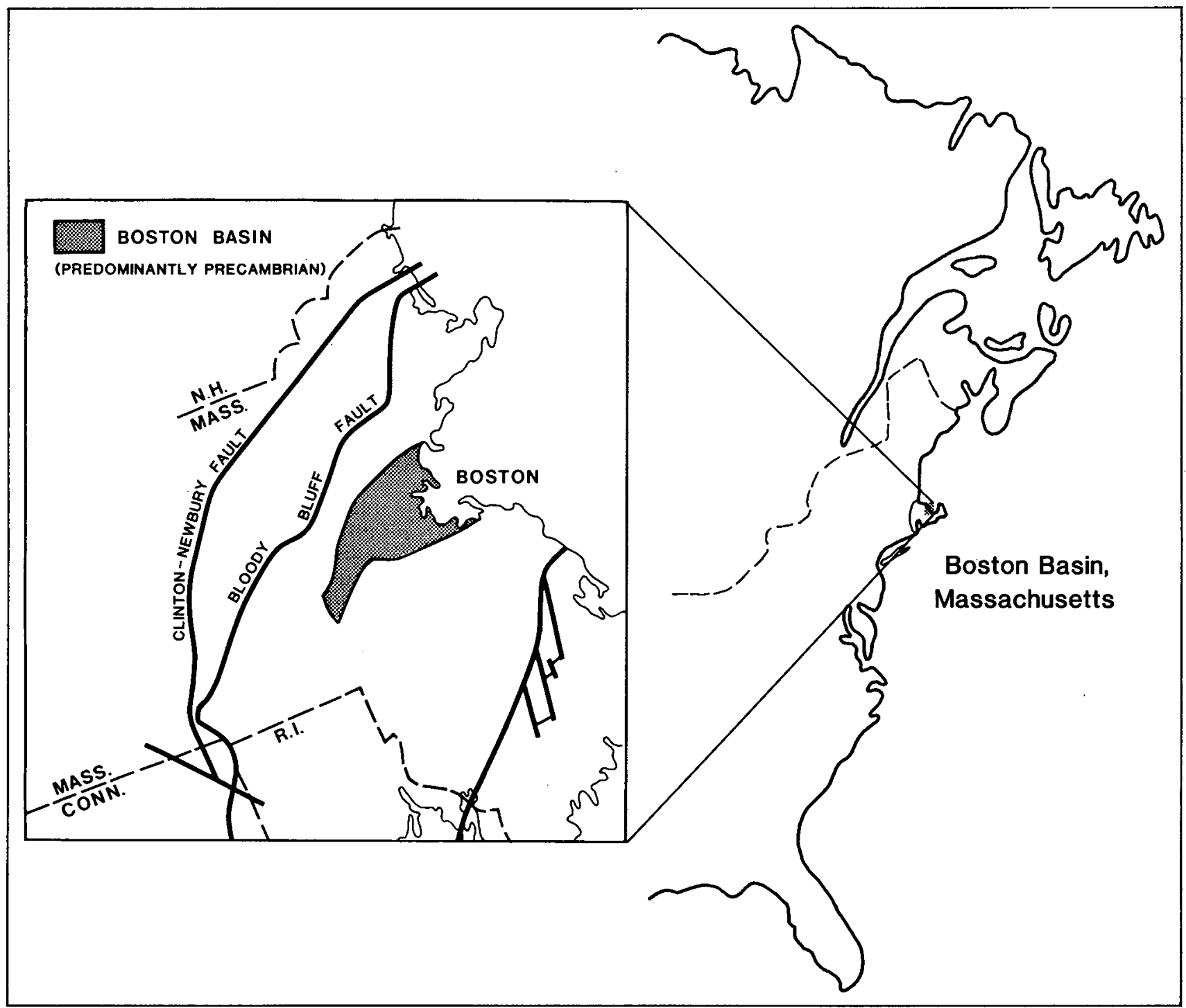

F1g. 1. Location of the Boston Basin, Massachusetts.

students, and co-workers; and 3) ambiguities housed in the original descriptions of the stratigraphic units, which appear to have led to confusion of stratigraphic units and structural relationships in the field (1.e. see LaForge, 1932). More importantly, our understanding of depositional systems, facies, and processes which has improved significantiy over time necessitating re-evaluation of the Boston Basin succession. In order to circumvent a significant portion of those historic problems cited above, the authors have opted to Identify and delineate facies within the basin as opposed to delineating and remapping stratigraphic units which were originally broadiy defined in the mid-to-late 1800's and early 1900's. The authors have been unable to overcome completely the lack of outcrop and the lack of subsurface information, but we are attempting to resolve these problems to some extent by extending our coverage of the basin through the use of recently located exploratory cores taken from various portions of the basin.
We use the term facies in this paper in a manner analogous to Mial1 (1977; 1978), and Eyles et al. (1983), to describe a combination of 1ithology, nature of clast support, internal organization, and a varlety of subjective features which can be used to help interpret and reconstruct the depositional system and setting. Facies is not used here as a synonym for 11thology or stratigraphic unit. The information which we have gathered over the past four field seasons has ylelded evidence for the emplacement and redeposition of a large volume of sediment, much of which is very coarse, by a variety of sediment gravity mechanisms as well as traction mechanisms. We have thus far amassed a substantive body of evidence which suggests that the bulk of late Precambrian sedimentary rocks in the Boston Basin was deposited on a slope (slope is used to infer only that the original depositional surface was inclined from the horizonta1) within a marine basin, and that ice played a major role in the transportation and deposition of this sediment. Furthermore, the basin-fill sequence records the 
tectonic evolution of the basin.

Inevitab1y, seismic stratigraphic techniques will have to be applied to the Boston Basin in order to document the basin type and to identify chronostratigraphic surfaces which can be traced across the basin and thereby establish a basis for testing those models such as ours which purport to explain the depositional and tectonic history of the basin.

\section{HISTORIC STRUCTURAL, STRATIGRAPHIC, AND} SEDIMENTOLOGIC FRAMEWORK OF THE BOSTON BASIN

The Boston Basin appears to be an extensional basin bounded by high angle reverse faults to the north, south, and west ( $F 1 g .2)$. The nature of its eastern boundary, assuming one exists, is not well known. The basin's granitic basement (Dedham Granite and cogenetic Mattapan Volcanics) is suggested to have intruded older crust which appears to have been subsequently deformed during the Avalon orogeny (Skehan, 1983; Skehan and Murray, 1980a). The nature of this older crust is obscure. Perhaps the original basement constituted the Nashoba, Marlboro, and Westboro Formations or their equivalents (Rast and Skehan, 1983). The entire succession records Alleghanian deformation in the form of east-northeast striking thrust faults and northeast-trending folds (Billings, 1979a; Skehan and Murray, 1980a; 1980b). The rocks appear to have been mildly deformed during the Acadian or Taconian orogeny (Skehan and Murray, $1980 \mathrm{a} ; 1980 \mathrm{~b})$.

Investigations into the stratigraphy of the basin date back to the mid-to-late 1800 's when Hitchcock (1861), Shaler (1871), Dodge (1883), Hobbs (1899), Sayles and LaForge (1910), Sayles (1914), Emerson (1917), LaForge (1932), and Billings (1939) first used the names of the stratigraphic units which, through continued usage, achieved formal stratigraphic status and came to be known collectively as the Boston Bay Group (Fig. 3). From the base to the top, the stratigraphy of the Boston Basin begins with the calc-alkaline Dedham Granite and Lynn Volcanics (Fig. 3). The isotopic age of the Dedham is reported to be 646 $595 \mathrm{Ma}$ (Zartman and Naylor, 1984). Non-comformab1y overlying the granite is a suite of bimodal volcanics (Mattapan Volcanics), the later phases of which have chemical affinities with extensional tectonic settings (Hon and Hepburn, 1986). Unconformably overlying these volcanics is the Boston Bay Group whose age is bracketed between late Vendian and early Cambrian (Kaye and Zartman, 1980 ; Lenk et al., 1982). The succession is capped by Cambro-Ordovician shales and sandstones (Weymouth Formation and Braintree Argilite) housing an Acado-Baltic trilobite-bearing fauna which links the Boston Basin to the Avalon platform. There is no agreement on the nature of the transition (conformable or unconformable) from the Boston Bay Group to the Cambro-Ordovician overlap sequence.

Historically, the lower portion of the Boston Bay Group, the Roxbury Conglomerate (F1g. 3), has perhaps been the most hotly contested, jet probably least we11 understood sequence within the Boston Basin (see Table 1 for a summary of historic interpretations of the Boston Bay Group). From the base up, the Boston Bay Group consists of the
Roxbury Conglomerate or Formation and the Cambridge Arglilite or Slate. The Roxbury Conglomerate is composed of three members which from the base to the top are the Brookline, the Dorchester, and the Squantum. Interpretations of the Squantum Member are varled and controverslal, and can be grouped into two broad general categorles (Table 1): glacial (terrestrial or marine) and non-glacial (terrestrial or marine).

One of the few cross-sectional reconstructions of the Boston Bay Group (Fig. 4) is that of Marland Blilings, his students, and co-workers (Rahm, 1962; Billings and Tierney, 1964; Billings and Rahm, 1966; Tierney et al., 1968; Richardson, 1975; and Billings, 1975) who, over a period of 15 years (1960-1975), mapped the geology of the basin within water and sewer tunnels beneath the city of Boston.

\section{LITHOFACIES OF THE BOSTON BAY GROUP}

As traditional stratigraphic and analytical approaches have not led to a resolution of the depositional history of the Boston Basin succession, we have adopted a more modern approach to basin analysis, that of identifying and classifying facles on a bed-by-bed basis, for the purposes of developing an actualistic facies model for the depositional history of the basin (see Eyles et al., 1983; and Mial1, 1978; for a discussion of these techniques). This reinvestigation is based in part on recent improvements in our understanding of sediment transport mechanisms, particular1y sediment gravity mechanisms (Middleton and Hampton, 1973; 1976; Enos, 1977; Lowe, 1976a; 1976b; 1979; 1982; Hampton, 1975; 1979; Rodine and Johnson, 1976; Carter, 1975; Nardin et al., 1979; and Komar, 1970). We have also abandoned traditional stratigraphic descriptions and subdivisions of the Boston Bay Group because we believe that the depositional history of the basin lies within the facles assemblages and assoclations, which are independent of the stratigraphy.

\section{Lithofacies Descriptions}

Lithofacies designations for the Boston Bay Group consist of a four letter code. The first letter of the code refers to one of three principal rock types: diamictites, sandstones, and fine-grained units (argillite), designated by the capita1 letters $D, S$, and $F$. The second letter of the code refers to the nature of the clast support, clast supported (c) or matrix supported (m). The third letter of the code refers to internal organization or bedding characteristics, massive and unstructured (m), stratified (s), and graded (g). The final letter of the code is bracketed, and refers to attributes of the facies that are interpretive. For example, the code (d) might be used to indicate the presence of dropstones. A list of the 1ithofacies types recognized in the Boston Bay Group is shown in Table 2. The non-genetic term "diamictite" is used to refer to any rock which contains a poor1y to moderately sorted mixture of clasts, sand, and mud. Furthermore, the term "diamictite" does not specify the abundances of particle sizes present, yet does accommodate both matrix-and clast-supported fabrics as we11 as degrees of organization of clasts and matrix (stratification and grading). 


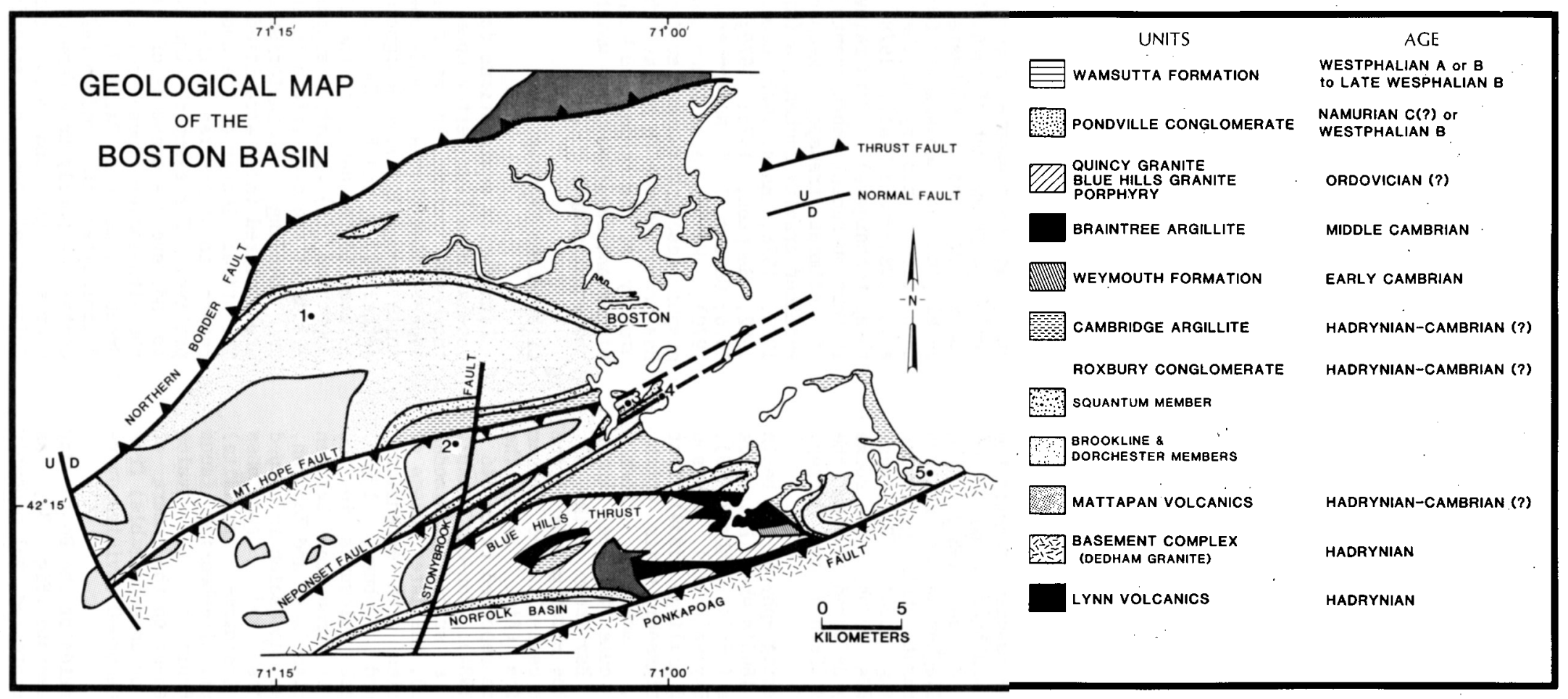

F1g. 2. Geologic map of the Boston Basin. Geology after Billings (1979a). Numbers refer to locations where stratigraphic sections were measured. 


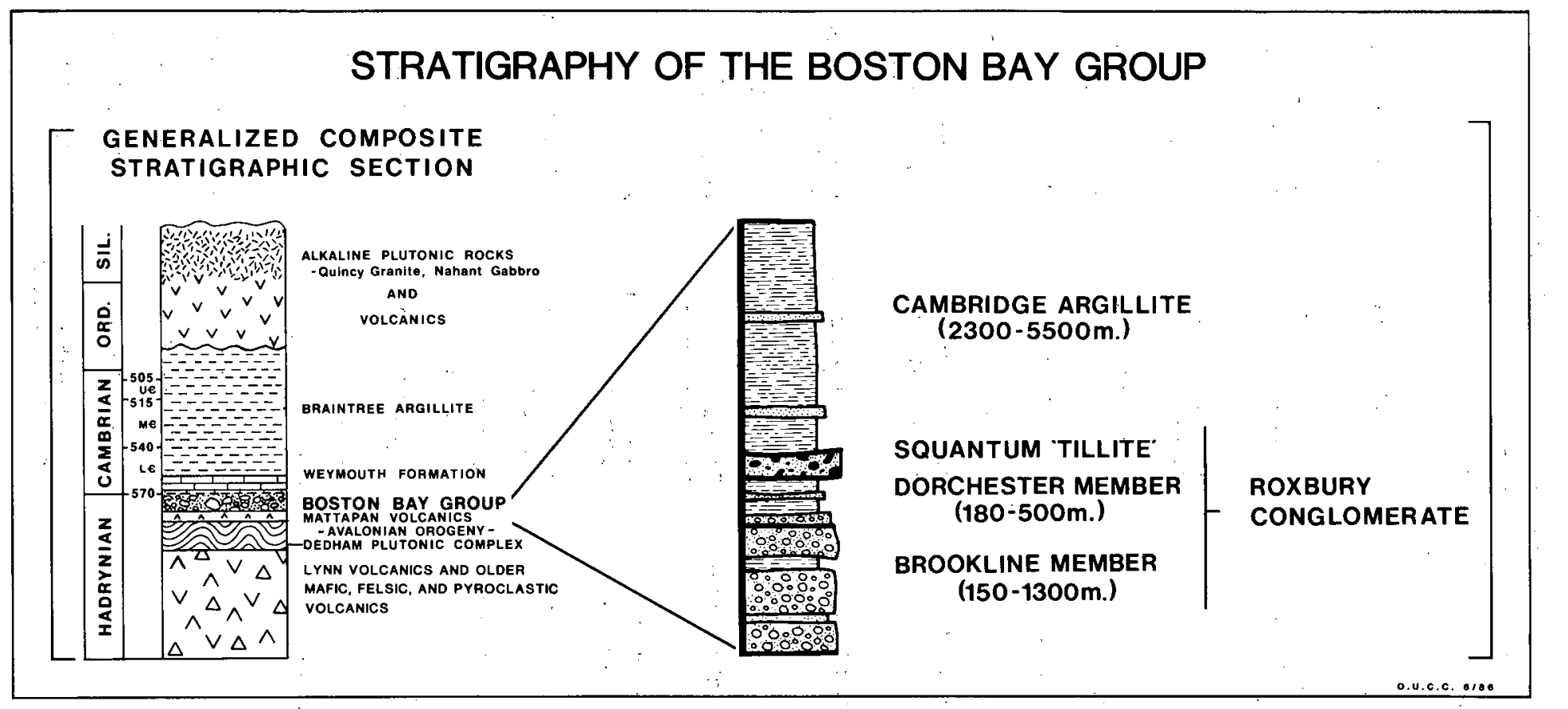

F1g. 3. H1storic stratigraphic units of the Boston Basin. Approximate thicknesses are from Bilitings (1979a). 
Table 1. A review of interpretations of the Boston Bay Group.

\begin{tabular}{|c|c|c|}
\hline Interpretation & Age & Reference \\
\hline $\begin{array}{l}\text { Piedmont glacier/sub- } \\
\text { aqueous mudflow }\end{array}$ & Ordovician-Permian & Bailey et al. 1976 \\
\hline $\begin{array}{l}{ }^{*} \text { Transitional alluvial } \\
\text { fan-braided stream- } \\
\text { marine ramp. }\end{array}$ & $\begin{array}{l}\text { late Precambrian- } \\
\text { Cambrian }\end{array}$ & $\begin{array}{l}\text { Bailey and Galli, 1985; } \\
\text { Bailey, in press }\end{array}$ \\
\hline $\begin{array}{l}\text { *A1luvial fan-braided } \\
\text { stream/glacial }\end{array}$ & $\begin{array}{l}\text { Pennsylvanian- } \\
\text { Permian }\end{array}$ & $\begin{array}{l}\text { Billings, 1929; 1976a; } \\
\text { 1976b; 1979a }\end{array}$ \\
\hline \multirow[t]{2}{*}{$\begin{array}{l}\text { *A1luvial fan-braided } \\
\text { stream/glacial }\end{array}$} & late Precambrian & $\begin{array}{l}\text { Billings, } 1979 b \text {; pers. } \\
\text { comm. } 1985\end{array}$ \\
\hline & Carboniferous & Burr and Burke, 1900 \\
\hline Subaqueous mudflow & & Caldwe11, 1964 \\
\hline $\begin{array}{l}\text { Intermontane glacial/ } \\
\text { lacustrine }\end{array}$ & $\begin{array}{l}\text { late Ordovician- } \\
\text { ear1y Silurian }\end{array}$ & $\begin{array}{l}\text { Cameron and Naylor, } \\
\text { 1976; Cameron and } \\
\text { Jeanne, } 1976\end{array}$ \\
\hline $\begin{array}{l}\text { Intermontane glacial/ } \\
\text { lacustrine }\end{array}$ & $\begin{array}{l}\text { late Precambrian- } \\
\text { Cambrian(?) }\end{array}$ & $\begin{array}{l}\text { Cameron, 1979a; 1979b; } \\
1979 c\end{array}$ \\
\hline * & Cambrian & Crosby, 1900 \\
\hline $\begin{array}{l}\text { Subaqueous debris flow/ } \\
\text { geosynclinal }\end{array}$ & $\begin{array}{l}\text { Devonian- } \\
\text { Mississsippian }\end{array}$ & Dott, 1961 \\
\hline $\begin{array}{l}{ }^{*} \text { Transitional alluvial } \\
\text { fan-fluviatile-deltaic }\end{array}$ & $\begin{array}{l}\text { late Precambrian- } \\
\text { Cambrian }\end{array}$ & Kaye, 1984 \\
\hline * & $\begin{array}{l}\text { late Precambrian- } \\
\text { Cambrian }\end{array}$ & Kay and Zartman, 1980 \\
\hline $\begin{array}{l}\text { *Alluvial fan-fluvial/ } \\
\text { glacial }\end{array}$ & $\begin{array}{l}\text { Devonian- } \\
\text { Carboniferous }\end{array}$ & LaForge, 1932 \\
\hline Glacia1 & late Paleozoic & Lahee, 1914 \\
\hline Mudf1ow & & Lindsay et al. 1970 \\
\hline \multirow[t]{3}{*}{$\begin{array}{l}\text { Glacial fluvial/ } \\
\text { lacustrine }\end{array}$} & Carboniferous & Mansfield, 1906 \\
\hline & & Naylor and Sayer, 1976 \\
\hline & Mississippian & Pollard, 1965 \\
\hline Glacial & Carboniferous & Rahm, 1962 \\
\hline *Marine/glacla1 & $\begin{array}{l}\text { late Precambrian- } \\
\text { late Carboniferous }\end{array}$ & Rehmer, 1981 \\
\hline Glacia1 & & $\begin{array}{l}\text { Rehmer and Hepburn, } \\
1974\end{array}$ \\
\hline $\begin{array}{l}\text { Glacial alluvia1- } \\
\text { lacustrine/subaqueous } \\
\text { mass flow }\end{array}$ & & Rehmer and Roy, 1976 \\
\hline Glacia1 & Permian & Sayles, 1914 \\
\hline
\end{tabular}


Table 1. Continued

\begin{tabular}{|c|c|c|}
\hline Interpretation & Age & Reference \\
\hline *Glacial lacustrine & $\begin{array}{l}\text { Permian- } \\
\text { Carboniferous }\end{array}$ & $\begin{array}{l}\text { Sayles and LaForge, } \\
1910 ; 1919\end{array}$ \\
\hline * & $\begin{array}{l}\text { late Precambrian- } \\
\text { Cambrian }\end{array}$ & $\begin{array}{l}\text { Skehan, 1979; Skehan } \\
\text { and Murray, 1980a; } \\
\text { 1980b }\end{array}$ \\
\hline $\begin{array}{l}{ }^{*} \mathrm{Glacial} \text { marine slope- } \\
\text { fan system }\end{array}$ & $\begin{array}{l}\text { late Precambrian- } \\
\text { Cambrian }\end{array}$ & $\begin{array}{l}\text { Smith and Socci, 1986; } \\
\text { in press }\end{array}$ \\
\hline $\begin{array}{l}{ }^{*} \text { Glacial marine slope- } \\
\text { fan system }\end{array}$ & $\begin{array}{l}\text { late Precambrian- } \\
\text { Cambrian }\end{array}$ & $\begin{array}{l}\text { Socci, 1984; 1985; } \\
\text { Socci and Smith, 1985; } \\
\text { 1985b; 1986a; 1986b; } \\
1986 \mathrm{c} ; 1986 \mathrm{~d} \text {; this paper }\end{array}$ \\
\hline * & $\begin{array}{l}\text { late Devonian- } \\
\text { Permian }\end{array}$ & Tierney et al. 1968 \\
\hline Glacial & - & Wolfe, 1976 \\
\hline
\end{tabular}

*Interpretations of the entire Boston Bay Group. A11 other interpretations pertain to the Squantum Member of the Roxbury Conglomerate.

N

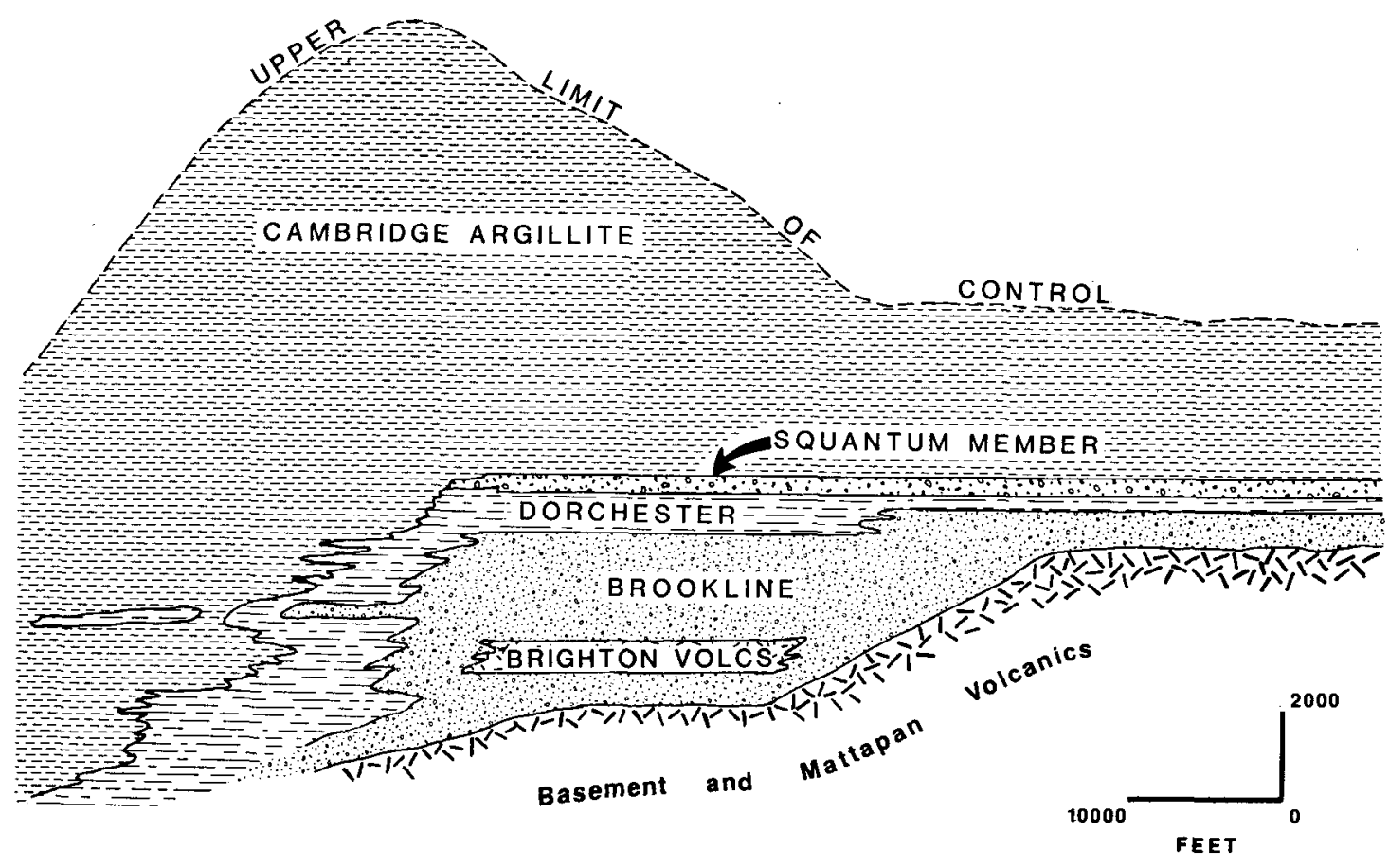

Fig. 4. Cross-sectional reconstruction of the Boston Bay Group (after Billings, 1979a). 
Table 2. Lithofacies types of the Boston Bay Group.

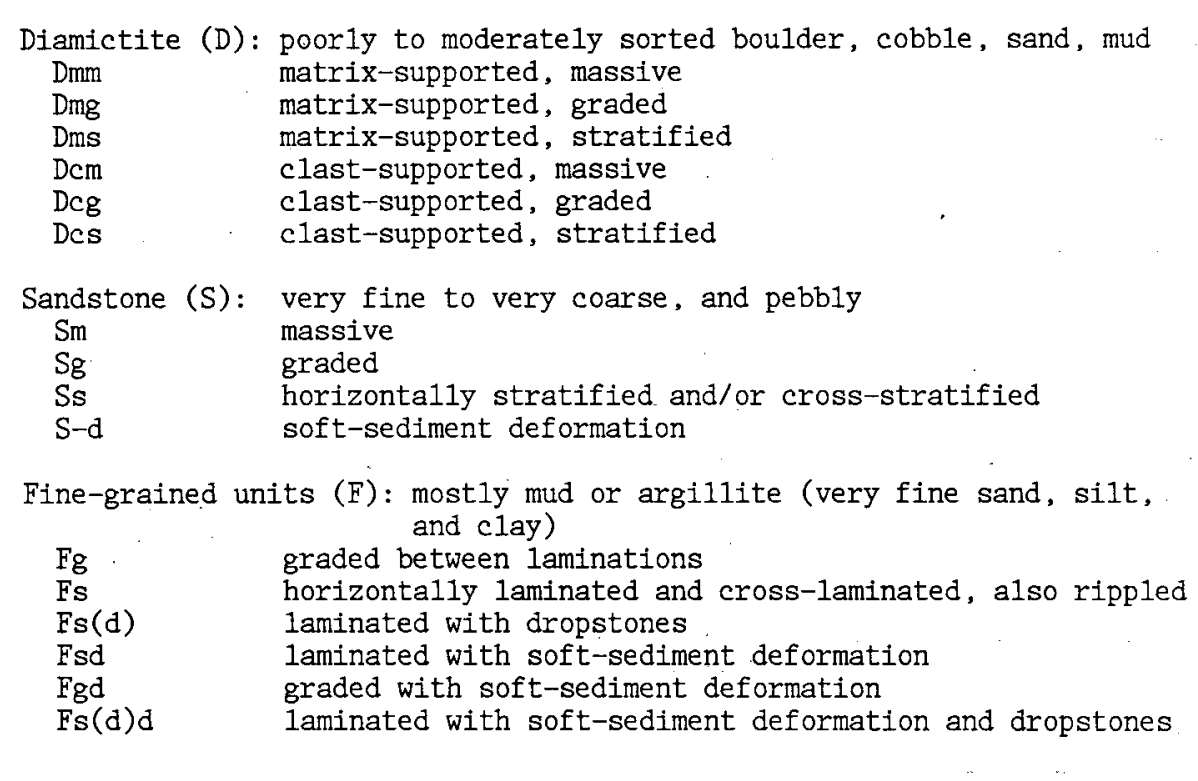

A graphic $10 \mathrm{~g}$ of coded measured stratigraphic sections of the Bay Group, as well as their locations, are shown in Figures 5 and 6 . Unfortunately, the only controls on the locations of stratigraphic sections are outcrop availability and accessibility. Such controls do not readily lend themselves to the construction of a we11constrained sedimentological model. However, the measured sections are representative of each of the historic stratigraphic subdivisions of the Boston Bay Group. We submit therefore, that there is sufficient stratigraphic control within the measured sections to formulate a somewhat 10osely constrained actualistic sedimentological mode1 for the depositional history of the Boston Basin.

Interpretive and descriptive data for each facies is presented in Table 3. The fabric of each facies is interpreted as being representative of a specific depositional mechanism (or mechanisms) suggested to have been responsible for the emplacement of the facies in question.

\section{Diamictites}

The diamictites in the Boston Bay Group are composed of a range of grain sizes from mud to very large boulders, some of which are in excess of $1 \mathrm{~m}$ in diameter. Clasts are predominately we11 to moderately well rounded, although subangular and faceted clasts are not uncommon. Compositiona11y, these rocks are composed of granite, bimodal volcanics, quartzites, and intraclasts of massive, graded, and laminated sandstone ( $\mathrm{Sm}, \mathrm{Sg} 1, \mathrm{Sg} 2, \mathrm{Ss} 1$, Ss2) and mudstone (Fsd; Figure 7A), some of which show soft-sediment deformation. All of the clasts vary in undetermined proportions from place to place.

The diamictites range from clast-supported (DC) to matrix-supported (Dm) within the same unit or within multistoried units. Massive as well as crudely to moderately we11 sorted, and normally and inverse1y graded diamictites ( $-m, D-s$, and $D-g$ ) are common. Clast density is also observed to vary commonly within units. Thicknesses of diamictite units range from centimeters to tens of meters, the latter, undoubted1y, are in many cases stacked or multistoried sequences representing a multiplicity of superimposed flows some of which have extremely faint contacts with the unit above and/or below. Many diamictites also have sharp, planar/irregular, erosive, channelized and/or loaded basal contacts.

\section{Sandstones}

The sandstone facies within the Boston Basin range in size from fine-grained to very coarsegrained to pebbly and cobbly. Composition of the sandstones ranges from feldspathic to 1ithic (volcanic, plutonic, and sedimentary) to quartzrich, becoming progressively more mature in composition as the grain size decreases. However, the relative proportion of each constituent is unknown from place to place. Individual beds vary in thickness from approximately 2 centimeters to roughly 10 centimeters where bedding contacts can be discerned. Thickness of sandstone bodies ranges from centimeters to tens of meters or more.

Fine-Grained Units (Argillites)

In general, the fine-grained facies consist of individual laminations which do not exceed a few mililmeters to a centimeter in thickness. However, aggregate thicknesses of stacked laminae approach a meter to tens of meters.

Volcanic Rocks

In addition to the facies listed in Table 3, there is a suite of volcanic rocks consisting of flows, dikes, sills, and water-lain(?) tuffs, within the Boston Basin (Fig. 3). Non-conform- 

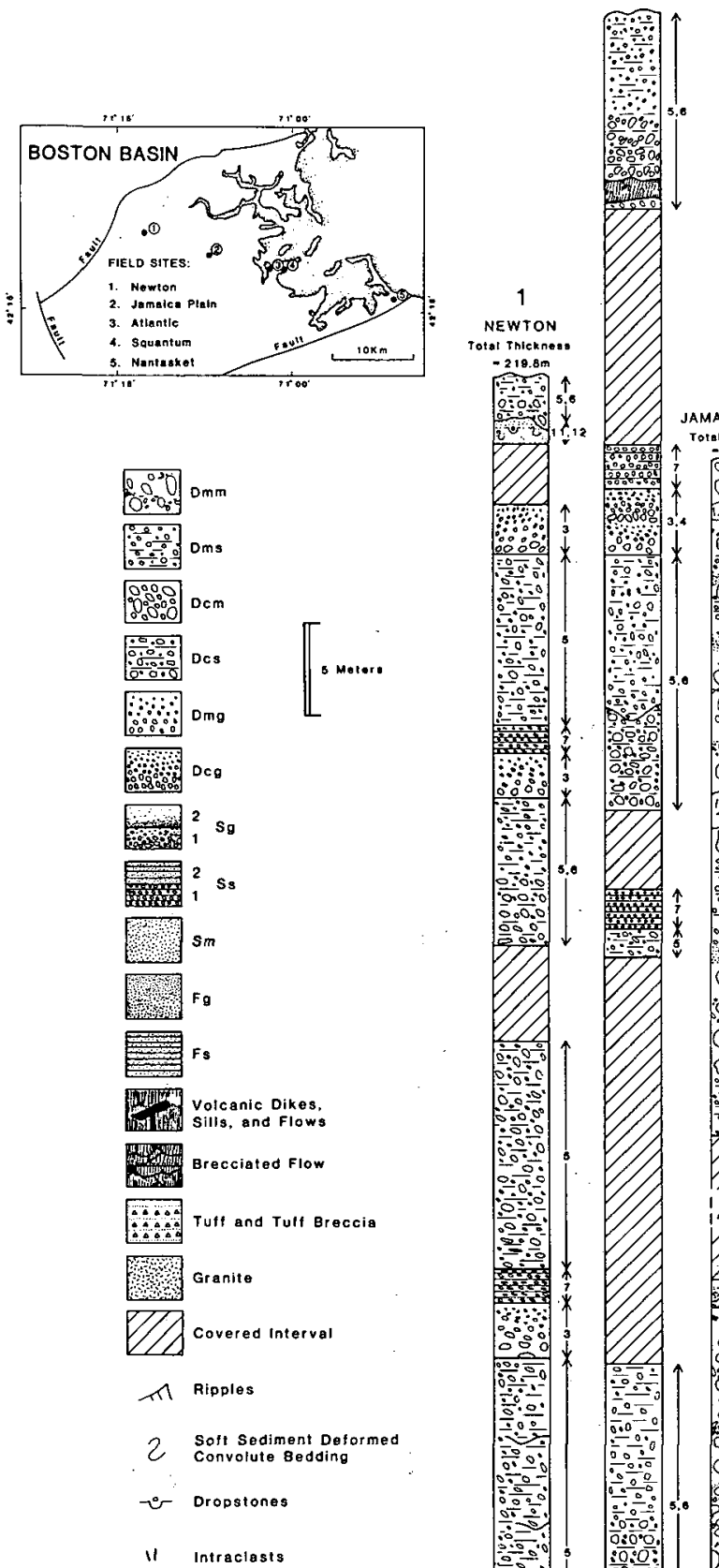

(a)
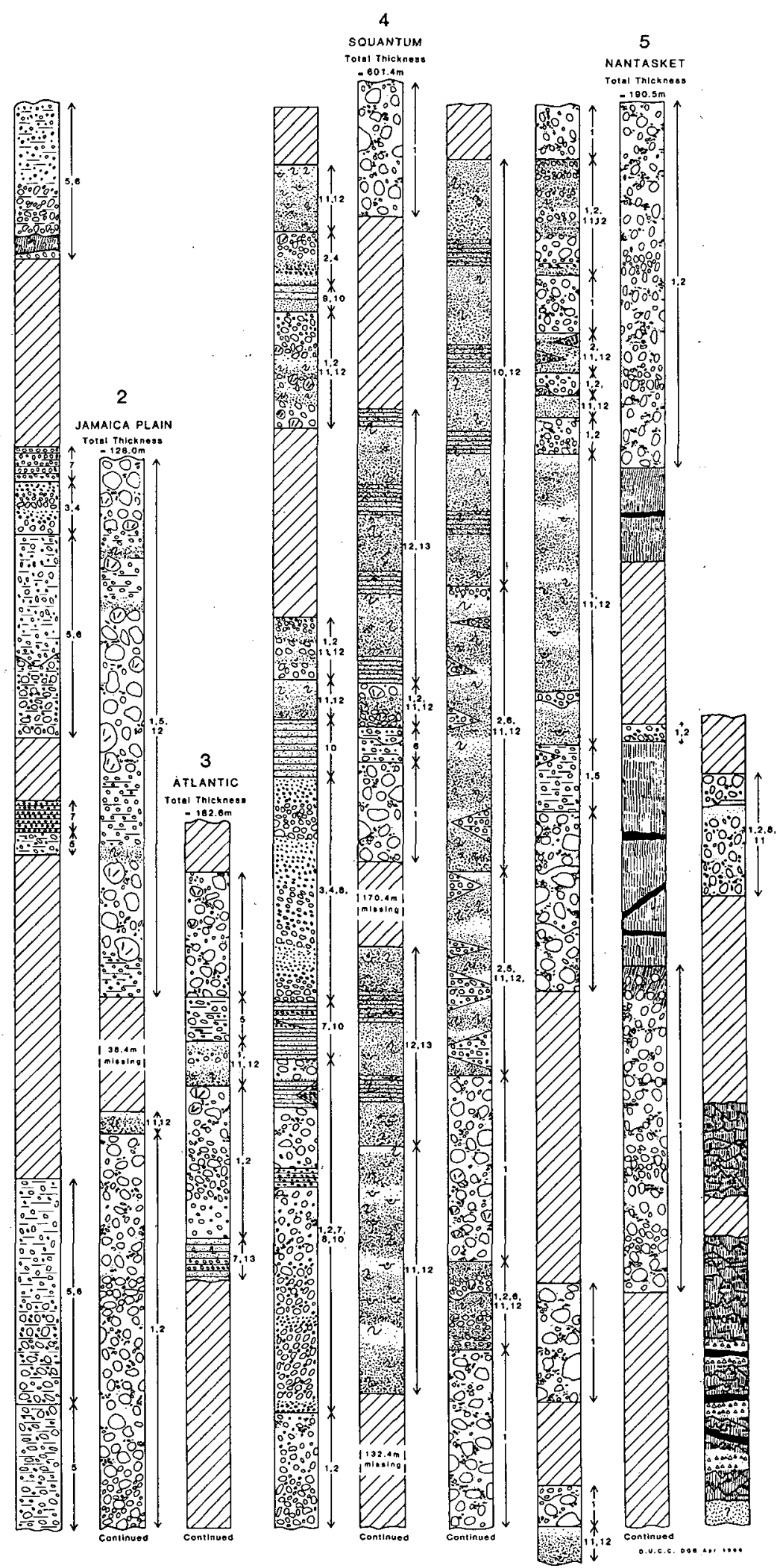

Fig. 5. Coded 11thofacies logs of measured sections of the Boston Bay Group. Section numbers at the top of each section refer to the location of each section and are also keyed to $\mathrm{F}_{\mathrm{g}}$. 2. To the right of each section are numbers that refer to flow types which are considered responsible for the emplacement of the facies shown. Each flow type is explained in Table 3. 


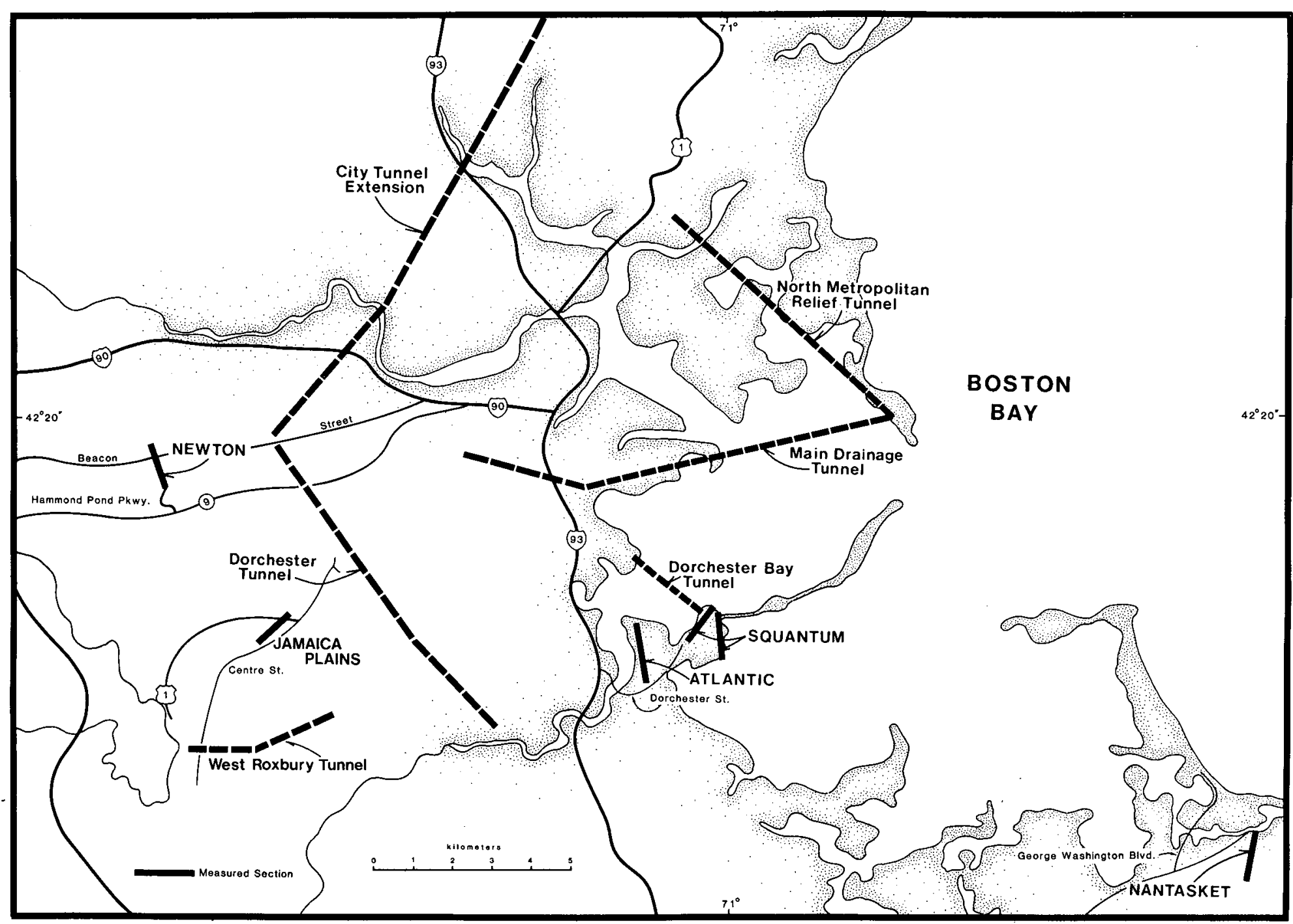

Fig. 6. Specific 1ocations of sections shown in Fig. 5 as well as the locations of tunnels, the geologic information from which was used to construct Fig. 4 . 
Table 3. Classification of facies and flow types within the Boston Bay Group.

\begin{tabular}{|c|c|c|c|}
\hline Type & Facies & Description & Interpretation \\
\hline 1 & Dmm & $\begin{array}{l}\text { Pebbles to boulders in a } \\
\text { somewhat sorted to unsorted } \\
\text { matrix of mud to very coarse } \\
\text { sand and pebbles. Clasts are } \\
\text { generally rounded but angular } \\
\text { varieties are also present. } \\
\text { Clast density changes often. } \\
\text { Reverse grading at the base } \\
\text { not common. Basal contact is } \\
\text { generally planar-irregular, } \\
\text { erosive or loaded with some } \\
\text { channelling. Intraclasts } \\
\text { present. }\end{array}$ & $\begin{array}{l}\text { Unsorted to slightly } \\
\text { sorted proximal debris } \\
\text { flows. }\end{array}$ \\
\hline 2 & Dem & $\begin{array}{l}\text { Similar to type } 1 \text { but clast } \\
\text { supported. Clasts are generally } \\
\text { slightly more sorted than those } \\
\text { found in type } 1 \text { deposits. } \\
\text { Matrix may also be more sorted } \\
\text { toward the coarser sizes than } \\
\text { type } 1 \text { deposits. Intraclasts } \\
\text { may be present. }\end{array}$ & $\begin{array}{l}\text { Clast-supported more } \\
\text { organized proxima1 } \\
\text { debris flows. }\end{array}$ \\
\hline 3 & Dmg & $\begin{array}{l}\text { Grading of clasts from boulder, } \\
\text { cobble or pebble grades (mostly } \\
\text { cobble and pebble) to coarse } \\
\text { and pebbly sandstone. Reverse } \\
\text { grading may also be present at } \\
\text { its base. Intraclasts may be } \\
\text { present. Planar, slightly } \\
\text { irregular, erosive and loaded } \\
\text { basal contacts. }\end{array}$ & $\begin{array}{l}\text { Partially sorted inter- } \\
\text { mediate debris flows. } \\
\text { More sorted than types } \\
1 \text { and } 2 \text {. }\end{array}$ \\
\hline 4 & Dcg & $\begin{array}{l}\text { Similar to type } 3 \text { but with a } \\
\text { greater density of clasts. } \\
\text { Loaded bases common. Intra- } \\
\text { clasts present. }\end{array}$ & $\begin{array}{l}\text { Clast-rich variety of } \\
\text { type } 3 \text { and possibly } \\
\text { better sorted inter- } \\
\text { mediate debris flows } \\
\text { than type } 3 \text { flows. }\end{array}$ \\
\hline 5 & Dms & $\begin{array}{l}\text { Similar to type } 1 \text { but having } \\
\text { some stratification of matrix } \\
\text { or clasts. More sorted than } \\
\text { type } 1 \text { deposits and strat- } \\
\text { ification of clasts usually } \\
\text { involves cobble and pebble } \\
\text { grades. Erosional and loaded } \\
\text { bases common. Some strat- } \\
\text { ification is crossbedded } \\
\text { cut-and-fill units. Intraclasts } \\
\text { present. }\end{array}$ & $\begin{array}{l}\text { Wel1-sorted proximal to } \\
\text { distal debris flows and/ } \\
\text { or (?)traction currents. }\end{array}$ \\
\hline 6 & Des & $\begin{array}{l}\text { Similar to types } 2 \text { and } 5 \text { but } \\
\text { having some stratification of } \\
\text { clasts and/or matrix, but with } \\
\text { a greater density of clasts } \\
\text { than type } 5 \text {. Loaded bases may } \\
\text { be present. Crossbedding may } \\
\text { also be present. }\end{array}$ & $\begin{array}{l}\text { We11-sorted, clast-rich } \\
\text { distal debris flows and/ } \\
\text { or (?) traction currents. }\end{array}$ \\
\hline 7 & Ss1 & $\begin{array}{l}\text { Horizonta11y and cross-strat- } \\
\text { ified pebb1y (occasional1y } \\
\text { cobbly) sandstone often fil1- } \\
\text { ing scoured depressions. }\end{array}$ & $\begin{array}{l}\text { Tractive phase of high- } \\
\text { density turbidites and/or } \\
\text { emplacement by (?) traction } \\
\text { traction currents. }\end{array}$ \\
\hline
\end{tabular}


Table 3. Continued

\begin{tabular}{|c|c|c|c|}
\hline Type & Facies & Description & Interpretation \\
\hline 8 & $\mathrm{Sg} 1$ & $\begin{array}{l}\text { Grading of unit from pebbly } \\
\text { (occasionally cobbly) and } \\
\text { granular sandstone to medium } \\
\text { to fine-grained sandstone and } \\
\text { siltstone. Basal contact is } \\
\text { often planar and possibly } \\
\text { erosive in places. Reverse } \\
\text { grading at the base may also } \\
\text { be present. }\end{array}$ & $\begin{array}{l}\text { High-density (proximal) } \\
\text { turbidites and/or } \\
\text { possibly fluidized/ } \\
\text { liquified flows. }\end{array}$ \\
\hline 9 & $\mathrm{Sm}$ & $\begin{array}{l}\text { Ungraded and unbedded fine to } \\
\text { medium grained sandstone with } \\
\text { loaded basal contacts. }\end{array}$ & $\begin{array}{l}\text { High-density (proximal) } \\
\text { turbidites/grain flows } \\
\text { and/or fluidized/liqui- } \\
\text { fied flows. }\end{array}$ \\
\hline \multirow[t]{2}{*}{10} & Ss2 & $\begin{array}{l}\text { Similar to type } 9 \text {, but having } \\
\text { faint to distinct strata. } \\
\text { Different from type } 8 \text { in that } \\
\text { the grain sizes are smaller. }\end{array}$ & $\begin{array}{l}\text { Low-density (distal) } \\
\text { turbidites and/or poss- } \\
\text { ibly distal fluidized/ } \\
\text { liquified flows and/or } \\
\text { traction currents. }\end{array}$ \\
\hline & & $\begin{array}{l}\text { Cross-stratification may also } \\
\text { be present. }\end{array}$ & \\
\hline 11 & $\mathrm{Sg} 2$ & $\begin{array}{l}\text { Medium to fine sandstone } \\
\text { grading to fine to silty } \\
\text { sandstone and siltstone. Bouma } \\
\text { BCD, BCDE(?), B(?)CD, CD, and } \\
\text { CDE(?) units present. }\end{array}$ & $\begin{array}{l}\text { Low density (dista1), } \\
\text { Bouma-type turbidites. }\end{array}$ \\
\hline 12 & $\mathrm{Fg}$ & $\begin{array}{l}\text { Graded very fine sandstone and } \\
\text { siltstone to siltstone and mud. } \\
\text { Scoured and loaded bases are } \\
\text { common. Grading usually within } \\
\text { laminae. }\end{array}$ & $\begin{array}{l}\text { Low-density (dista1), } \\
\text { Bouma-type turbidites. } \\
\text { Possibly weak bottom } \\
\text { currents with suspension } \\
\text { settling. }\end{array}$ \\
\hline 13 & Fs & $\begin{array}{l}\text { Horizontal and cross-laminated } \\
\text { argillites, including ripples. } \\
\text { Planar and sometimes scoured } \\
\text { basal contact. }\end{array}$ & $\begin{array}{l}\text { Weak bottom currents and } \\
\text { suspension settling. }\end{array}$ \\
\hline 14 & Fs(d) & $\begin{array}{l}\text { A variant of } 13 \text { with the addit- } \\
\text { ional presence of lonestones. }\end{array}$ & $\begin{array}{l}\text { Variant of type } 13 \text { with } \\
\text { dropstones suggesting } \\
\text { sediment rain-out. }\end{array}$ \\
\hline 15 & Fsd & $\begin{array}{l}\text { A variant of types } 13 \text { and } 14 \\
\text { with load casts and/or slump- } \\
\text { folds. }\end{array}$ & $\begin{array}{l}\text { Variant of types } 13 \text { and } \\
14 \text { yet also having down- } \\
\text { slope gravitational creep } \\
\text { and rapid sedimentation } \\
\text { on underconsolidated } \\
\text { beds. Syn or post-deposi- } \\
\text { tional. }\end{array}$ \\
\hline 16 & Fgd & $\begin{array}{l}\text { A variant of type } 12 \text { but also } \\
\text { having slump-folds and load } \\
\text { casts. }\end{array}$ & $\begin{array}{l}\text { Variant of types } 12 \text { but } \\
\text { also having downslope } \\
\text { gravitational creep and } \\
\text { rapid sedimentation on } \\
\text { underconsolidated beds. } \\
\text { Syn or post-depositional. }\end{array}$ \\
\hline 17 & $F s(d) d$ & $\begin{array}{l}\text { Same as types } 13,14 \text {, and } 15 \text {, } \\
\text { but containing dropstones. }\end{array}$ & $\begin{array}{l}\text { Same as types } 13,14 \text {, } \\
\text { and } 15 \text {. }\end{array}$ \\
\hline
\end{tabular}



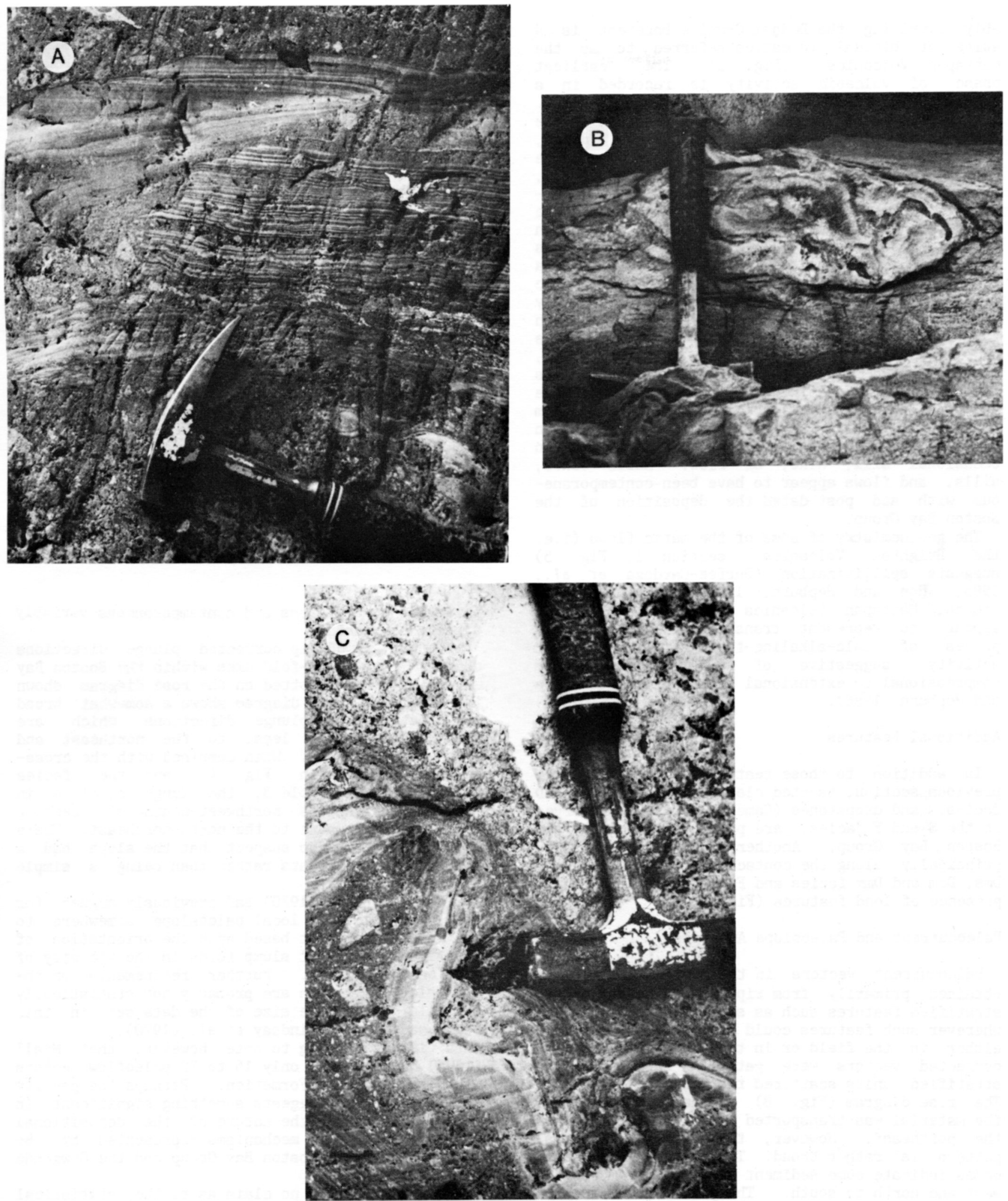

Fig. 7. Sedimentary features within the Boston Bay Group. (A) Cobble-rich diamictite (Dmm) with soft-sediment deformed argillitic (Fs) rip-ups in the upper portion of section 3. (B) Stratified water-lain? basalt/basaltic andesite tuffs contalning volcanic bombs 1ocated at section 5. (C) Load-casting below the base of a proximal debris flow deposit (Dmon-Dem factes) attributed to rapid loading of underconsolidated and fluidized sediments (Fs-Fg facies) located at section 3. Crude reverse grading is present at the base of the Dcm unit. 
ably overlying the Dedham Granite basement is a suite of bimodal volcanics referred to as the Mattapan Volcanics (Fig. 3). The earliest phase of volcanic activity is recorded in a succession of felsic or rhyolitic flows and tuffs. A later phase of volcanic activity resulted in the emplacement of water-lain(?) tuffs, flows, dikes, and sills of basalt and/or basaltic andesite (LaForge, 1932; Be11, 1948; Durfee-Cardoza et al., 1985; and Hon and Hepburn, 1986). These waterlain(?) tuffs, exposed in the southern part of the basin (see section 5, Fig. 5), commonly contain volcanic bombs (Fig. 7B) and terrigenous detritus. Directly overlying the tuffs is a massive (tens of meters thick) autobrecciated mafic flow which is reported to have been hydrothermally altered (LaForge, 1932; Be11, 1948). E1sewhere in the southern part of the basin terrigenous rocks and volcanics become complexly interstratified, laterally and upsection. Furthermore, there is typically a gradual increase, upsection, in the amount of terrigenous material present in the form of Dmm, Ss1, and Ss2 facies until the succession becomes completely dominated by detritus with an occasional sill, dike, or flow. Mafic dikes, sills, and flows appear to have been contemporaneous with and post-dated the deposition of the Boston Bay Group.

The geochemistry of some of the mafic flows (i.e. the Brighton Volcanics, section 1, Fig. 5) suggests spillitization (Durfee-Cardoza et al., 1985; Hon and Hepburn, 1986). In genera1, the bimodal Mattapan Volcanics (section 5, Fig. 5) appear to represent transitional early-to-1ate phases of calc-alkaline-to-alkaline magmatic activity suggestive of a transition from compressional to extensional tectonic regimes (Hon and Hepburn, 1986).

\section{Additional Features}

In addition to those features described in the previous section, faceted clasts, confined to the $\mathrm{D}$ facies, and dropstones (Cameron, 1979c), observed in the $S$ and $F$ facies, are present throughout the Boston Bay Group. Another common feature found principally along the contacts between Dmg, Deg, Dms, Dcm and Dmm facies and Fs and Fg facies is the presence of load features (Fig. 7C).

\section{Paleocurrent and Paleoslope Analysis}

Paleocurrent vectors in the Boston Basin were obtained primarily from ripples and other crossstratified features such as scour-and-fill features wherever such features could be found and resolved either in the field or in the laboratory. Dipcorrected vectors were gathered from 24 crossstratified units scattered throughout the basin. The rose diagram (Fig. 8) suggests that much of the material was transported from the southwest to the northeast. However, the overall dispersal pattern is rather broad. Two smaller secondary modes indicate some sediment dispersal from east to west and north to south. The paleocurrent vectors reveal a complex and varied flow pattern which reflects changing sourcelands and current directions through time and/or a multiplicity of contem-

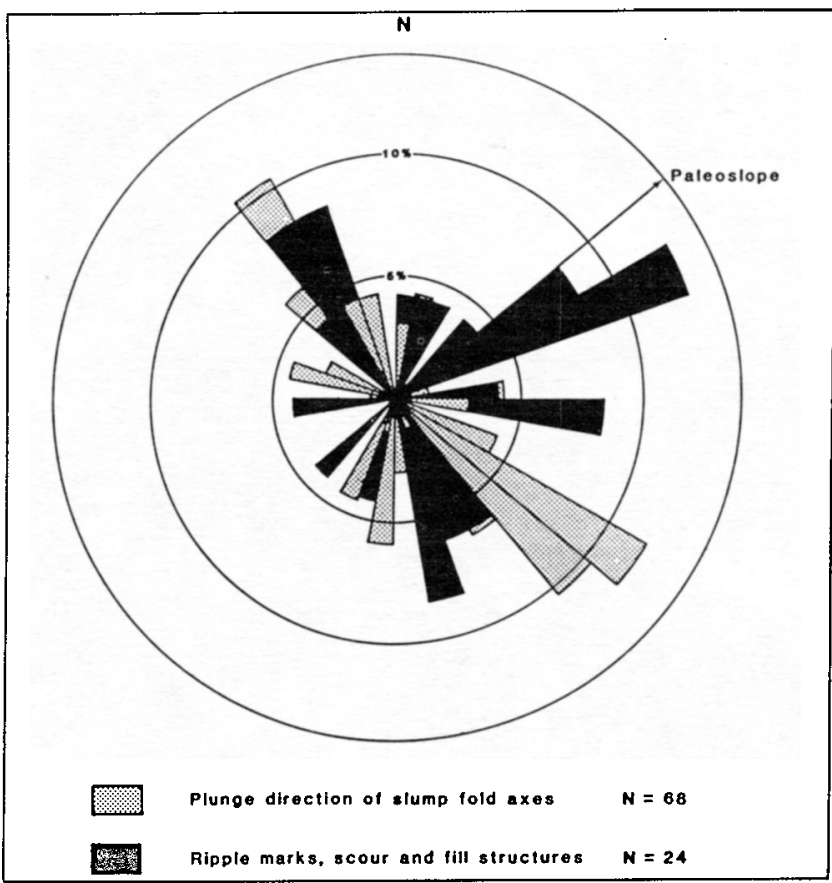

Fig. 8. Rose diagram of paleocurrent azimuths from crossstratified untts and plunge directions of slump-fold axes.

poraneous source areas and contemporaneous variably directed currents.

A total of 68 dip-corrected plunge directions obtained from slump-fold axes within the Boston Bay Group were also plotted on the rose diagram shown in Fig. 8. The diagram shows a somewhat broad distribution of plunge directions which are confined, more or less, to the northeast and southwest quadrants. When combined with the crosssection shown in Fig. 4 and the facies information in Table 3 , the plunge azimuths in Fig. 8 suggest a northwest-southeast trending paleoslope somewhere to the north-northeast. There is also reason to suspect that the slope had a number of reentrants rather than being a simple linear feature.

Lindsay et al. (1970) had previously argued for the existence of a local paleoslope somewhere to the north-northwest based upon the orfentation of the axial planes of slump folds in the vicinity of section 4 (Fig. 5). Further refinements on the paleoslope direction are probably not statistica11y possible given the size of the data set in this study and that of Lindsay et al. (1970).

It is interesting to note however, that Mial1 (1985) had obtained on1y 15 to 20 paleoflow vectors from the Gowganda Formation. Perhaps the paucity of flow vectors suggests something significant in itse1f regarding the nature of the depositional settings and flow mechanisms represented by the facies within the Boston Bay Group and the Gowganda Formation.

The authors make no claim as to the statistical reliability of the data in Fig. 8 since the information obtained was predicated upon outcrop avallability and accessibility. 


\section{INTERPRETATION}

\section{Diamictites}

Most of the diamictites in the Boston Bay Group are interpreted as resedimented detritus redeposited largely by sediment gravity mechanisms. F1ow types 1 through 6 are interpreted as an evolutionary sequence of debris flow and turbidite facies (proximal to distal) generated on a slope as the debris flows and turbidity currents attenuated downslope producing vertical and within-flow variations in fabric.

Walker $(1975 ; 1984)$ has stated that debris flows are initially disorganized in proximal settings and that as the flows move further downslope basal reverse grading in accompaniment with poor-tomoderate sorting develops in response to the establishment of dispersive pressure within the flows. As internal sorting further improves in the downslope direction, the flow may pass through a norma11y graded phase due to turbulence. Hampton (1972) observed that flow separation effects on debris flow noses can filter out fine sediment and produce a turbidity current which will outdistance the debris flow. Flow separation is a mechanism which improves the sorting in debris flows. In Hampton's (1972) model, turbidite sands would be the logical and genetically linked downslope facies equivalent of debris flows higher up on the slope.

Nelson and Nilsen (1984) have observed and described similar debris flow and turbidite fabrics in proximal and distal portions of submarine fans. Kurtz and Anderson (1979) and Anderson et al. (1983) have also described on the Antarctic she1f, diamictons, tens to hundreds of kilometers in length, in which the fabric changes downslope are analagous to the downslope (north) fabric changes within the diamictites of the Boston Basin.

Type 1 flow deposits (Table 3), facies Dmm, are unsorted, disorganized to varying degrees, matrixsupported diamictites which commonly contain boulders (Fig. 9A). These are interperted as proximal debris flow deposits laid down on the upper reaches of a relatively steep slope. The clasts were likely supported by cohesive strength, buoyancy, and turbulence (Hampton, 1979; Lowe, 1979). In places where reverse grading is present, dispersive pressure appears to have played an important role in supporting clasts, for some unknown amount of time, at least near the base of such flows (Middleton and Hampton, 1973). Intraclasts may also be present in Dmn deposits.

Type 2 flow deposits (Dcm) are considered to be variants of type 1 deposits. The amount of matrix present is generally substantially less than that found in flow type 1 , in addition to the fact that a significant proportion of the clasts are in contact or nearly in contact with other clasts. Yet the overall differences between flow types 1 and 2 are minor and are interpreted to have resulted from some degree of sorting of the matrix and the clasts due possibly to flow separation at the head of a debris flow. Consequently, the Dcm flow type is interpreted to be a more well sorted variant of a type 1 proximal debris flow deposited on a steep slope. There is a complete gradation in texture between flow types 1 and 2 . Reverse grading is rarely seen at the base of Dcm deposits. Loaded bases and intraclasts may be present in Dem deposits.

Flow types 3 and 4 (Dmg, Dcg) are commoniy characterized by changes in the density of clasts throughout the deposits (Fig. 9B), known as coarse-tail grading (Middleton and Hampton, 1973), wherein the coarsest fraction alone is normally graded and sorted due to the existence of turbulence during deposition (Lowe, 1982). These deposits may likely be the counterparts to the graded deposits described by Walker (1975; 1984) and Miall (1983; 1985), who have interpreted this fabric as representing debris flows deposited on less steep slopes than the deposits of flow types 1 and 2. This type of grading is suggested to be found in high concentration sediment-gravity flows in which turbulence has begun to diminish, while competency has changed throughout the flow (Middleton and Hampton, 1973). The distinction between clast and matrix-supported varieties of graded diamictites is difficult to make in the field due to the frequency with which clast density changes. Intraclasts are not uncommon in Dmg and Dcg deposits although basal reverse grading is common. Flow types 3 and 4 are here interpreted as intermediate debris flows which have undergone some sorting, while conceivably being deposited on less steep parts of a slope.

Flow types 5 and 6 (Dms; Dcs) represent a spectrum of stratified diamictites in which the proportion of matrix to clasts varies frequently, comprising a genetic family of facies similar to types 1 and 2 and types 3 and 4 , although the entire spectrum of diamictite facies represents a broader class of genetically related deposits. Facies types 5 and 6 are interpreted as distal debris flow deposits and/or high-density turbidites having a traction carpet phase of deposition. These types of deposits have also been described and discussed by Walker (1975; 1984) and Miall (1985). Stratification types represented by these facies also include cross-stratified sequences often filling scoured depressions.

\section{Sandstones}

Most of the sandstone 1ithofacies ( $\mathrm{Sg} 1$; $\mathrm{Sg} 2$; $\mathrm{Ss} 1$; Ss2,; Sm) are considered to have been emplaced by a variety of sediment-gravity flows such as high density turbidites/grain flows, low density turbidites, and liquified and/or fluidized flows, which together can account for the majority of fabrics and sedimentary structures observed in the sandstones such as normal and reversed graded bedding, cross-stratification, horizontal stratification, ripples, convolute bedding, load-casted features, and water-escape structures (see Middleton and Hampton, 1973; 1976; Lowe, 1976a; 1976b; and 1979).

In addition to interpreting the bulk of the sandstone facies as having been emplaced by sediment gravity flows, many are also suggested to have been genetica11y linked to proximal debris flows further up on the slope via flow separation phenomena whereby the finer sediment is continually removed from the debris flows, leaving the coarser debris flow deposits partlally sorted. However, in some cases there need not have been any genetic links between sediment gravity flow mechanisms and some sandstone and diamictite facies. Sandy 

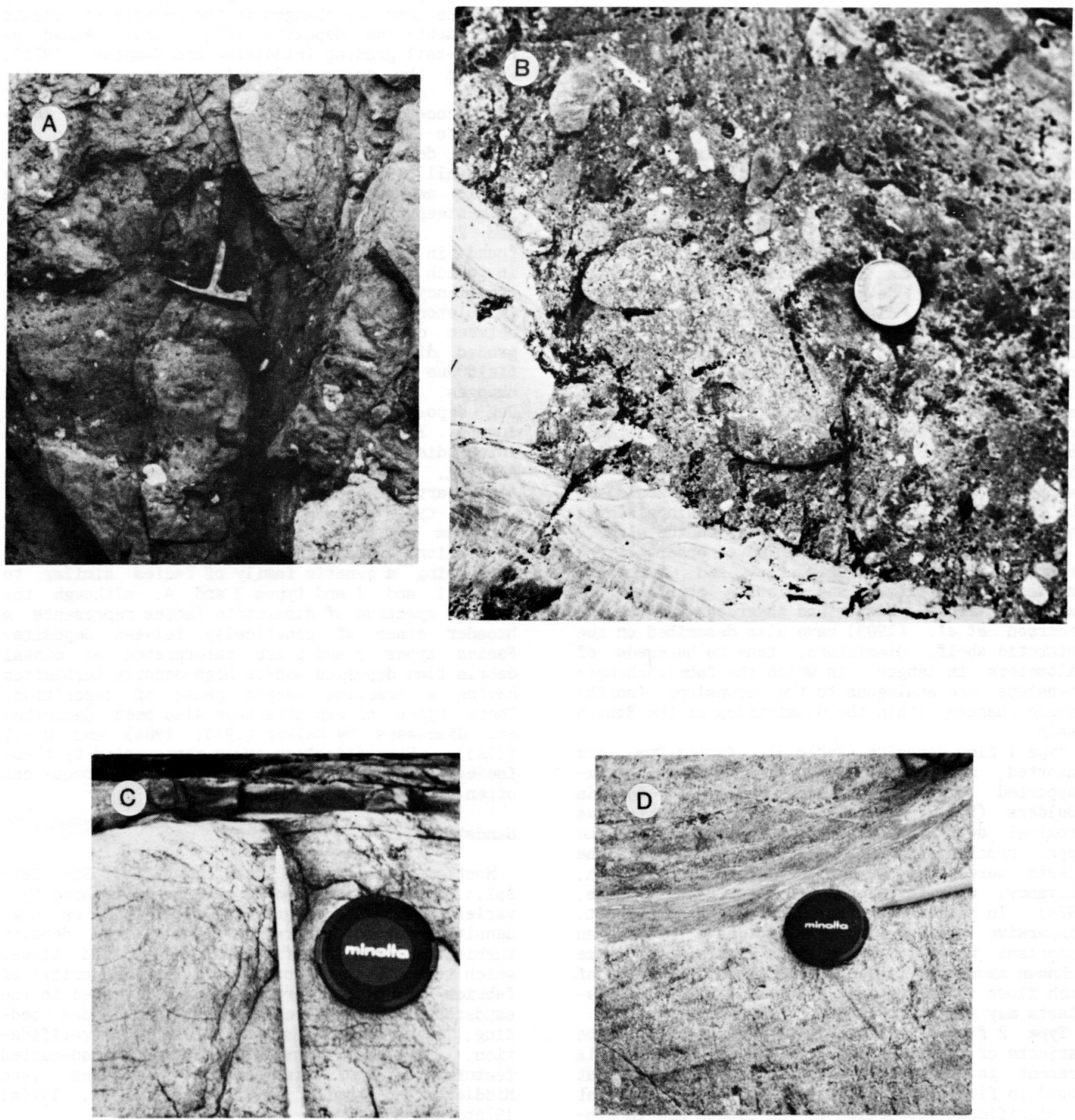

Fig. 9. Facies and flow types within the Boston Bay Group. (A) Unsorted, bouldery, matrix-supported proximal debris flow deposit (Dmm) located near the base of section 4. Falnt traces of bedding within the matrix can be observed below the hammer. (B) Crudeig graded, clast-poor intermediate-to-distal debris flow deposit (Ding) overlain and underlain by argililtes (Fsd) located at section 4. (C) Stacked, massive, medium-to-fine-gralned sandstone (Sm), possibly graded near the top, deposited by low density turb1dity currents and/or liquefied/fluldized flows located at section 3. Note the presence of concave-up fluld escape structures. (D) Medium-to-fine-grained, cross stratified, scour-filled sandstone (Ss2) possib1y deposited by low-density turbidity currents and/or bottom currents located at section 3. (E) Multistoried sequence of medium-to-fine-grained, normally graded Bouma-type B(?)CD and CD turbidites (Sg2) with loaded, convolute bedding located at section 4. (F) Granitic dropstone in Fs(d) facies located at section 4. (G) Stacked sequence of graded, soft-sediment deformed argillitic units (Fgd). Individual laminations are interpreted as lowdensity, Bouma-type CD B?CD CDE? turbidites with erosive bases. Some reworking by bottom currents may also have occurred. Slumpfolds are attributed to downslope creep. 

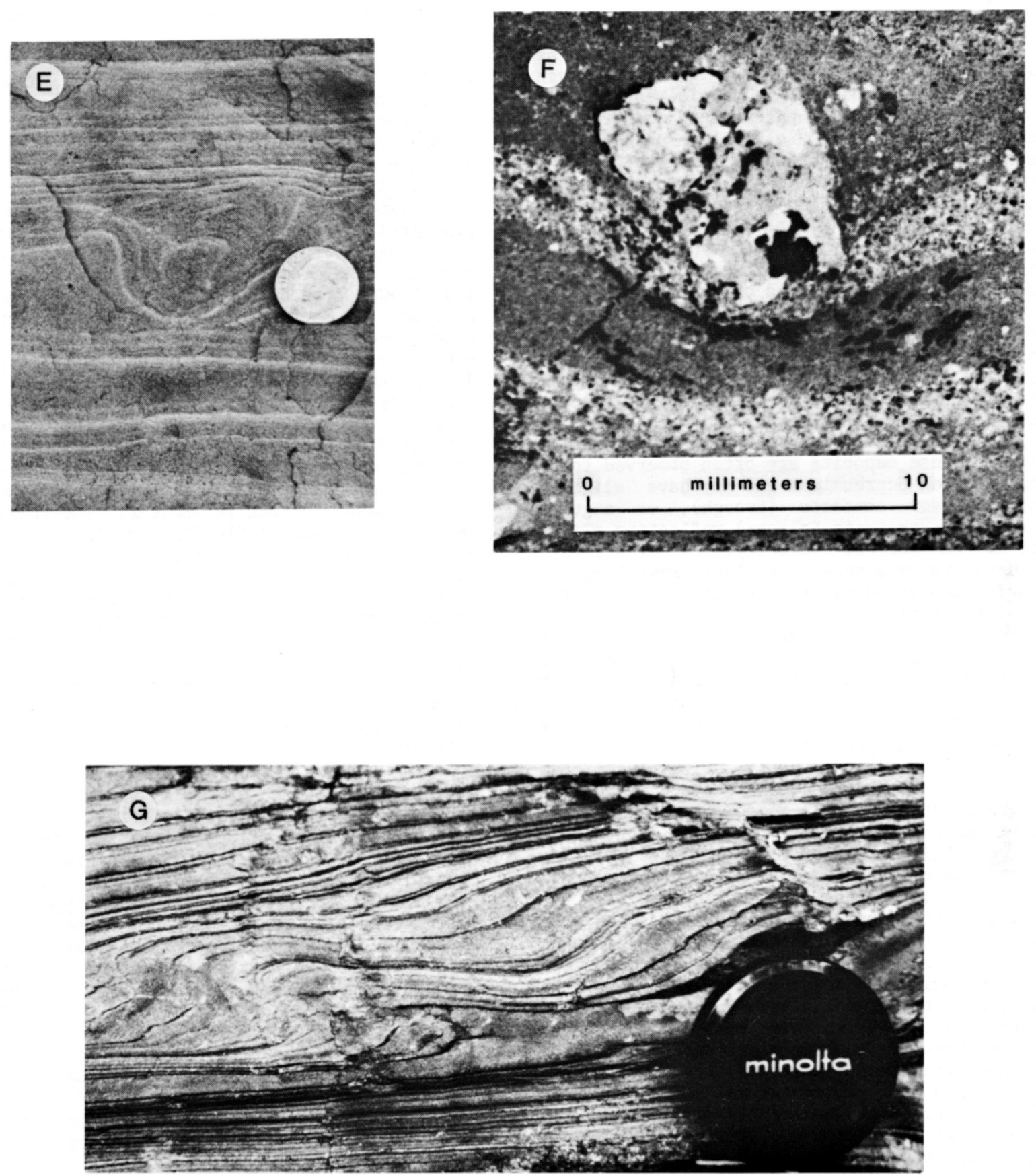
sediment gravity flows for example, could have been generated independently of debris flows, and no doubt this has occurred in the Boston Basin. The intimate association of sandstones and diamictites argues for a closer association between sediment gravity flow mechanisms.

Stratified and cross-stratified sandstone facies (Ss1; Ss2) may in some cases be interpreted as having resulted from wind-driven or tide-driven bottom currents. However, one should bear in mind that sediment gravity mechanisms such as turbidity currents often pass through a tractive phase while attenuating and depositing sediment. Such mechanisms also have the capacity to transport cobble-size material. Wind-driven or tide-driven bottom currents are not considered to be sufficiently energetic in this type of setting (slope) to transport and deposit coarse clasts.

Flow type 7 (Ss1) consists of horizontally to cross-stratified pebbly, occasionally cobbly, medium-to-coarse grained sandstones. The clast compositions are similar to those reported for the diamictites. Changes in the proportions of clasts present are unknown. This facies is interpreted as representing a deposit produced during the tractive phase of a high-density turbidity current moving downslope. These deposits are often observed to be filling scoured depressions and may have slightly tangential lower contacts (trough), or angular lower and upper contacts (planar) reflecting slight variations in current velocity. Alternatively, these deposits may merely reflect reworking of previously deposited material by bottom currents. However, as stated previously, bottom currents, in the absence of turbidity currents, are genera11y thought to be too weak to move coarse sediment in this setting. Again, the intimate association with diamictites as well as the slightly unsorted appearance of the sandstones favor emplacement by sediment gravity mechanisms.

F1ow type 8 ( $\mathrm{Sg} 1$ ) is a pebbly (with occasional cobbles), granular, or coarse-grained sandstone which grades normally to a medium- to fine-grained sandstone and/or siltstone. The basal contact is planar, slightly irregular, and possibly erosive. Basal reverse grading may also rarely be present. The clast compositions are analogous to the compositions found in the diamictites, and the relative proportions of these clasts are unknown. Flow type 8 is interpreted as having been deposited on a slope during the suspension stage of a high density turbidity current. Rare reverse grading at the base is thought to have been generated by dispersive pressure during a preceeding traction carpet phase (see Lowe, 1982). Alternatively, this flow type may have originated to some extent by liquified or fluidized sediment gravity flows in which particle support and motion result from rapidly escaping pore fluids leading ultimately to a tighter packing. However, the former interpretation is favored by the authors because of the coarseness of the clasts present, the absence of fluid escape features, and the presence of what appear to be erosive bases. In at least one instance the $\mathrm{Sg} 1$ facies was interpreted as constituting a multistoried unit deposited as a bar-like feature associated with Dmm and Dcm facies which in some instances had channelized basal contacts (see section 1, Fig. 5).

Flow type 9 deposits $(\mathrm{Sm})$ are non-bedded, non- graded, massive, medium- to fine-grained sandstones which often have loaded, non-erosional bases and are commonly associated with laminated fine-grained units (Fig. 9C). These deposits are interpreted as being generated by high-density turbidity currents during the latter stages of rapid suspension sedimentation accompanied by rapid entrainment of fluid. As the fluid subsequently escaped, the deposits were fluidized/1iquefied, temporarily mobilizing or remobilizing the sediments, producing fluid escape structures. These flow types are also considered to be equivalent to the Bouma $\mathrm{Ta}$ division of "classical" turbidites (Lowe, 1982).

F1ow type 10 deposits (Ss2) are similar to Sm flow deposits. They are composed of medium- to fine-grained, horizontally and cross-stratified sandstones (Fig. 9D). Laminations are also quite common. The cross-stratified units exhibit planar and trough type foresets and are often observed to fill scoured depresssions. Smal1-scale ripples are also occasionally present. These stratified sandstones are interpreted as having been produced during the passage and attenuation of low density turbidity currents over the distal portions of a slope. Deposition during tractive phases is indicated by cross stratification and the presence of filled scours. In instances where only horizontal stratification is present and the nature of the basal contact is unclear, the fabric could be related to distal fluidized or liquified flows, as suggested by Mial1 (1985). Additionally, some of these deposits could be the result of bottom currents. However, for the coarser sandstones it is considered likely that the currents which transported them were assoclated with turbidity currents.

Flow type 11 deposits (Sg2) consist of normally graded medium- to fine-grained sandstones which pass upward into fine-to-silty sandstones and siltstones (Fig. 9E). Compositionally, these deposits show a marked increase in mineralogical maturity. They range from feldspathic-rich to quartz-rich with occasional lithics. These deposits are also compositionally unlike the coarser sandstone facies such as $\mathrm{Sg} 1$ and $\mathrm{Ss} 1$ which are mineralogical1y immature (1ithic sandstones), but very similar in composition to flow types 9 and 10 . Type 11 deposits are interpreted to be low density or Bouma-type (dista1) turbidites laid down during the tractive and settling phases of sedimentation as turbidity currents attenuated, conceivably in the distal reaches of a slope.

Similar downslope changes in fabric and composition have also been observed in diamicton/sand, and diamictite/sandstone sequences on the present-day Antarctic Shelf (Wright and Anderson, 1982; Anderson, pers. comm., 1985) and in the Gowganda Formation (Miall, 1983; 1985), respective1y. In genera1, the $\mathrm{Sg} 2, \mathrm{Sm}$, and $\mathrm{Ss} 2$ facies are considered to be the mineralogically and physically sorted residuum of coarser deposits which came to rest higher (more proximally) on a slope as sedimentgravity flows moved downslope and attenuated.

Fine-Grained Units (Argillites)

Lithofacies type 12 deposits ( $\mathrm{Fg}$ ) consist of normally graded very fine sandstones and siltstones which pass upward into siltstones and clay. They are generally quartz rich, as are most of the $F$ 
facies types, and are interpreted to be the remnants of distal turbidites deposited from weak, low density turbidity currents during tractive and settling depositional phases as the flows attenuated downslope. Some of these deposits have scoured bases which may be related to the passage of turbidity currents, or to bottom current activity predating the passage of turbidity currents. Sma11-scale loaded bases with sma11-scale flame structures are fairly common. Some of these deposits may also have been deposited entirely from suspension, but the presence of load features suggests that sedimentation was rapid and took place upon a weak1y consolidated and fluidized substrate.

Type 13 flow deposits (Fs) consist of horizontal and cross-laminated argilites whose composition is similar to type 12 deposits. Cross-laminated stratification is confined to small-scale scourand-fill features and smal1-scale ripples. These deposits are interpreted as having been laid down and/or subsequently reworked by weak bottom currents independent of sediment-gravity flows. Suspension settling with reworking is also suggested to have occurred.

Type 14 flow deposits (Fs(d)) are similar to type 13 deposits, yet contain lonestones which often deform and sometimes penetrate stratification planes and are interpreted as dropstones (Fig, 9F). Types 15, 16, and 17 flow deposits (Fsd; Fgd; Fs(d)d) are similar to types Fg, Fs, and Fs(d). Yet, in addition, flow deposits 15, 16, and 17 record the presence of soft-sediment deformation such as load-casted features and slump-folds (Fig. 9G). The deformation is interpreted to have occurred during or immediately after sedimentation while the sediments were unlithified and undercompacted. Loading is thought to have resulted from rapid sedimentation upon fluidized, loosely-packed sediment with and without simultaneous downslope movement of the units. Slump-folds are considered to have been produced by the downslope creep of weakly consolidated beds under the force of gravity. Folding was also probably facilitated by poor packing resulting from undercompaction.

\section{Facies Associations}

Facies types 1 through 12 are considered to represent a spectrum of flow deposits laid down on a slope. The upper (proximal) region of this slope is characterized by the presence of bouldery Dmm, Dmc, and Dms facies (sections 3-5, Fig. 5) which contain soft-sediment deformed rip-ups (Fsd) and deformed, commonly laminated, matrix. This deformation and these facies are considered to be the result of sediment rain-out or basal washout from melting she1f ice or icebergs, which loaded unconsolidated sediment and overloaded the slope producing a variety of debris flows as well as other sediment-gravity flows which moved downslope generating facies 3-12 as the flows attenuated. Some $\mathrm{Dcm}$ and $\mathrm{Dmm}$ facies have channelized basal contacts whereas others have very irregular somewhat planar contacts which, in some cases, are suggested to have resulted from sediment rain-out (rapid suspension sedimentation from melting ice) rather than having been transported along the bottom. To the north and obliquely downslope the diamictites gradually become slightly less bouldery and slightly more sorted while the matrix also undergoes some sorting (see Fig. 5). Diamictites and sandstones rarely contain stratified and graded argillitic and sandy soft-sediment deformed rip-ups in the vicinity of location 1 . Stratified and graded diamictites (Dms; Dcs; Dcg; and Dmg) and stratified and graded sandstones (Ss1; Ss2; $\mathrm{Sg} 1$; and $\mathrm{Sg} 2$ ), as we11 as graded and deformed finegrained units ( $\mathrm{Fg} ; \mathrm{Fgd})$, become volumetrically more important in the downslope direction to the northnortheast. Channelized features, including the presence of planar and trough crossbedded, scourfill diamictites (Dms; and Des) and what appear to be bar deposits ( $\mathrm{Sg} 1-\mathrm{Sg} 2$ facies), are prominent in the vicinity of section 1 (Fig. 5). A graded, slumped argillite sequence $(\mathrm{Fg}(\mathrm{d}) \mathrm{d} ; \mathrm{Fig} .9 \mathrm{G})$ at location 1 is interpreted as either a channe1-fill deposit or a more regional sedimentation event marked by a lower rate of sedimentation and the presence of less competent depositional mechanisms. Dropstones occur in nearly all of the fine-grained units in the basin (Fig. 9F).

Fine-grained units gradually become volumetrically more important to the north, presumably in the lower reaches of the slope/basin where no section was measured due to the lack of outcrop but for which there exists historical information (1.e. see Fig. 4). In general, finegrained units and sandstones are suggested to have been associated with lower sedimentation rates coupled with a significant drop in the available energy within the depositional setting (lack of competent depositional mechanisms).

There is reason to believe that as sediment gravity flows slowly moved downslope and attenuated they did not necessarily come to rest at exactly the same position on the slope. Some flows outdistanced others while other sediment gravity flows were probably remobilized several times before finally being incorporated into the stratigraphic record. The net effect of this was the generation of dramatic and abrupt facies changes in the younging direction. These facies exhibit no direct linkage to the adjacent facies (i.e. Dmm or Dmc facies directly overlying Fs or Fg facies and vice versa; see section 1, Fig. 5). Alternative1y, abrupt facies changes which are, or may once have been more regional in extent prior to differential erosion, may be related to climatic changes (episodic ice growth and decay) and/or tectonic readjustments in the basin and/or the sourcelands. However, since many of the finegrained units show varying degrees of erosion, the original extent of these units is unclear.

There is also no reason to presume that turbidity currents were, in all cases, directly linked to debris flows generated higher up on the slope. Many such flows undoubtedly originated independently of debris flows.

It should also be remembered that the principal controls on the locations of the stratigraphic sections shown in Fig. 5 were the availability and accessibility of outcrop. The sections therefore provide brief glimpses into the full range of facies present within the basin and do not permit a detailed accounting of continuous changes in fabric within flows in the downslope direction. Our on1y notion of lateral facies changes comes from our 
understanding and application of the concept of facies development within a vertical sequence (see Visher, 1965).

Depositional Model for the Evolution of the Boston Basin

Historically, there appears to have been a great deal of confusion regarding the stratigraphy and hence the depositional history of the Boston Basin (i.e. see LaForge, 1932). To some extent this confusion is 1ikely to have evolved from continued usage of the original stratigraphic subdivisions within the Boston Basin which did not adequately characterize the variety of textures present and which often came replete with an interpretation. In addition, although there are scores of published papers dealing with the stratigraphy and sedimentology of the Boston Basin, there has been 1ittle progress in inventorying and identifying the fundamental components of the Boston Bay Group (i.e. facies), while even fewer papers housed any data which could be used in combination with other data to formulate a coherent, less contentious, geologic history of the basin. The net effect has often lead to apparent misconceptions and oversimplifications of the geology and make-up of the Boston Basin succession (see Smith and Socci, in press).

Although the present authors have been able to recognize a suite of facies which can and have been used to construct a depositional model for the Boston Basin, we have found no marker beds or stratigraphic horizons which would permit the identification of lithostratigraphic or timestratigraphic units. It is our belief, therefore, that the stratigraphy of the Boston Bay Group will be resolved through shallow and deep seismic stratigraphy and/or biostratigraphic markers.

From the information we have thus far gathered on the 1ithofacies of the Boston Bay Group, it appears that there is much more complexity in the make-up and distribution of lithofacies assemblages. The facies patterns are a function of the rate of subsidence due to thermal cooling, the rate of subsidence due to the rate of sedimentation, the rate of sea level change due to changes in ridge volume and sedimentation, the rate of sea leve 1 change due to climate, and the rate of sediment supply, which is a complex function of climate, rates of sea-level change, and the rate of tectonism. Of the rate controls cited above, climate and tectonics appear to have most greatly influenced the sedimentation patterns in the Boston Basin. In time however, the influence of climate on the pattern of sedimentation appears to have given way to tectonic influences on sedimentation patterns.

\section{Stage 1}

The Boston Basin appears to have originated as a successor (possibly arc) basin in an extensional or trinstensional setting following the closing of the Cadomian(?) Ocean (Rast and Skehan, 1983) in the late Precambrian. During the subduction of Cadomian ocean crust (Avalonian Orogeny), calcalkaline granites (Dedham and equivalents) were emplaced in a compressional or transpressional setting, into older crust (Middlesex Fells Volcanic
Complex and basement (?), the nature of which is unresolved. Subsequent deformation of the Middlesex Fells Volcanics, the Dedham Granite, the Lynn Volcanics, and older crust (?) heralded the end of the Avalon Orogeny, which also marked the closing of the Cadomian ocean. Near the end of the Precambrian, the appearance of the bimodal Mattapan Volcanics, marked by an early calc-alkaline phase of activity and a later alkallne phase (Hon and Hepburn, 1986), is suggested to have represented a transition from a compressional tectontc regime to one of extension.

Questions concerning the age of the Boston Basin, as well as the basin type, are closely tied to whether or not the Boston Bay Group (the basin fili) contains Avalonian deformation. If Avalonian deformation is not present within the Boston Bay Group, then it is reasonable to argue that the basin post-dated the closing of the Cadomian Ocean and the Avalon Orogeny, and is therefore more likely to be a successor-type basin which originated on an Andean-type active margin during an extensional tectonic regime. In time, the basin filled with loca11y-derived (?) plutonic, volcanic, and sedimentary detritus. Alternatively, if the Boston Bay Group does record Avalonian deformation, then it is feasible to suggest that the basin had to have formed prior to closure of the Cadomian Ocean, and is therefore more likely to have originated as an arc-type basin within a compressional tectonic regime. Presently, this question remains unresolved. The authors however, have observed cleaved clasts, principally granites, whose cleavage planes appear to be random1y oriented, with no apparent relation to the orientation of the more pervasive Alleghanian cleavages. Therefore, in the absence of any clear evidence of pervasive Avalonian deformation within the Boston Bay Group, the Boston Basin is presumed to be a successor basin which post-dated arc formation and volcanism.

Sometime during, and possibly just post-dating, the earliest (felsic or rhyolitic) and later (mafic) phases of bimodal volcanic activity, a period or erosion ensued as suggested by the presence of an unconformable surface on top of the Dedaham Granite and on top of the felsic component of the Mattapan Volcanics. The nature of this uncomformity is not we11 known nor would such a surface be required to be present everywhere. During or sometime after this erosional event, mafic volcanics in the form of stratified waterlain tuffs with volcanic bombs and occasional granitic pebbles (see section 5, Fig. 5) were deposited contemporaneously with the emplacement of dikes, sills, and flows of basalt and basaltic andesite (Fig. 10A). The presence of anomalously high sodium concentrations in these tuffs (LaForge, 1932; Be11, 1948; and Hon and Hepburn, 1986) suggests that the Boston Basin was in contact with marine waters early in its history. A later phase of mafic volcanic activity produced a thick sequence of hydrothermally altered autobrecciated flows.

The next phase of sedimentation and basin evolution was characterized by the deposition of large volumes of volcanic, plutonic, and sedimentary detritus in the form of bouldery debris flows (Drm, Dcm) Into a widening (?) and thermally subsiding (?) marine basin. These interbedded volcanic flows 
and tuffs, and bouldery debris flow deposits are considered to represent the initial stages of slope progradation and aggradation within a newiy emerging successor basin. Reworking of these debris flow deposits by variably directed bottom currents is suggested by the presence of multiply oriented ripples in fine-grained sandstone near the base of the succession (section 5, Fig. 5).

Stage 2

The next major episode in the evolution of the Boston Basin is considered to have been a period of rapid submarine slope/fan progradation and aggradation (Fig. 10B) marked by the development of complex facies associations and the appearance of large volumes of coarse detritus (diamictites). Sediment rain-out on the slope from floating shelf ice and/or icebergs led to overloading of undercompacted, fluidized sediment generating sediment gravity flows such as debris flows which moved downslope in a norther1y-northeasterly direction leaving in their wake proximal debris flow deposits (Dmm, Dmc, and Dms) containing soft-sediment deformed argilittes ( $\mathrm{Fgd}, \mathrm{Fsd}$ ) representing a prior episode of slow deposition of fine-grained sediment. As the debris flows continued downslope, they slowly attenuated giving rise to other sediment gravity flows such as turbidity currents and liquified/fluidized flows which carried away the finer materials that were originally present in the debris flows, and leaving behind sorted, stratified, and graded proximal to distal debris flow deposits and turbidites (Dms, Dcs, Dmg, Dcg). On the lower, deeper parts of the slope turbidity currents and liquified/fluidized flows produced graded, stratified, and massive sandstones (Ss1, $\mathrm{Ss} 2, \mathrm{Sg} 1, \mathrm{Sg} 2, \mathrm{Sm})$ and graded argillites $(\mathrm{Fg})$. In the vicinity of the toe (?) of the slope/fan and elswhere, fine-grained sediments were reworked and redeposited by bottom currents. Channellzed features were present everywhere on the slope but appear to have been more abundant some distance downslope.

There appear to have been intermittent periods of climatic amelioration conceivably brought about by Milankovitch-type orbital forcing and/or periodic rises in eustatic sea-level independent of climate. During such times sedimentation rates were significantly reduced, and the slope/fan accumulated blankets of fine-grained sediment in the absence of a mechanism (or mechanisms) capable of transporting coarse detritus into the basin (F1g. 10C). Slope fallure continued during these episodes of more equable climates, but at much reduced rates presumab1y due the absence of coarse detritus which would ordinarily have overloaded the slope/fan with greater frequency. Abandoned channels were filled with fine-grained, graded deposits containing dropstones $(\mathrm{Fg}(\mathrm{d}))$ released

\section{BOSTON BASIN : (INITIAL RIFTING)}

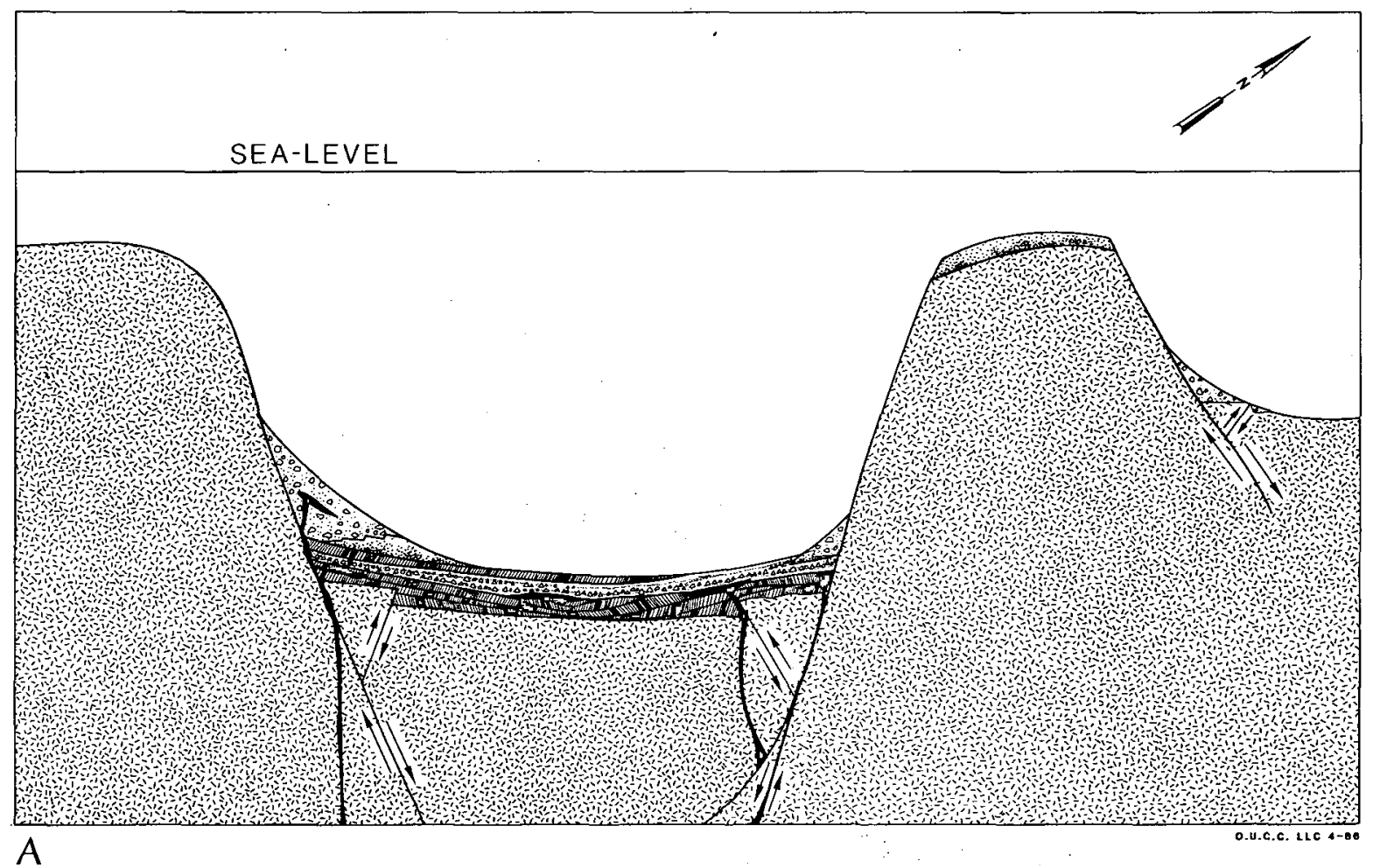

Fig. 10. Preliminary depositional model for the evolution of the Boston Basin. (A) Initial rifting phase of basin evolution with concurrent bimodal volcanism and detrital sedimentation within a marine? basin. (B) Slope buflding phase of basin evolution brought about by climatic controls on sedimentation. (C) Shelf building phase of basin evolution resulting from 1) c1lmate amelioration, if) slope aggradation resulting in an elevated platform, and 1i1) a tectonocally-driven rise in eustatic sea level. Historic stratigraphic names of the units comprising the Boston Bay Group have been assigned to stages B and C for the purpose of identifying the 11kely positions of those units in the context of this model. 


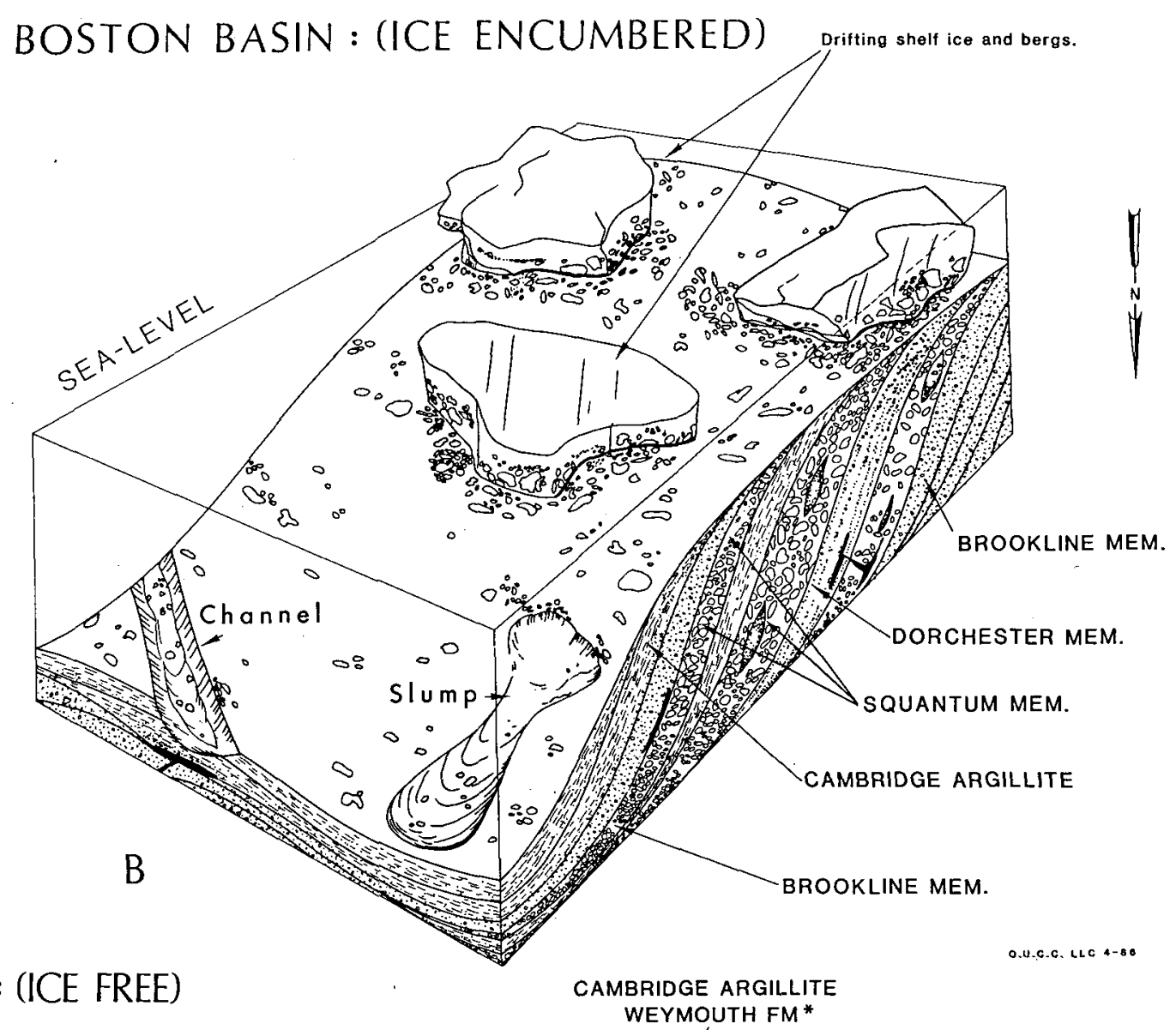

\section{BOSTON BASIN : (ICE FREE)}

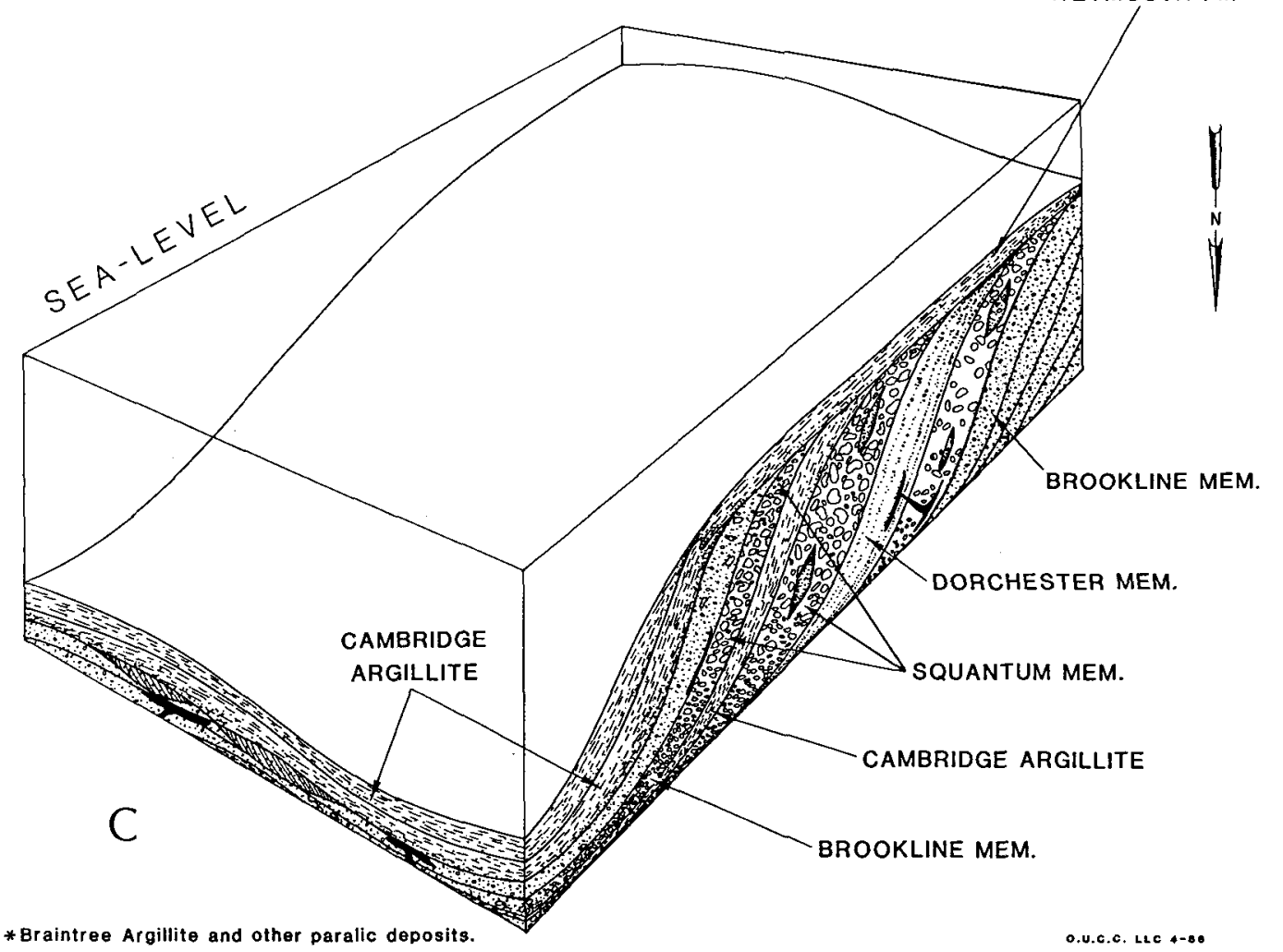

Fig. 10 Continued 
from sma11, scattered 1cebergs. In some instances the channel fill began to creep and slump downslope probably due to slope instability and undercompaction. Bottom currents also reworked previousiy deposited fine-grained sediment.

In the deeper, more distal area of the slope/fan, the presence of acritarchs records evidence of pelagic sedimentation in marine waters (Kno11, pers. comm., 1986). Furthermore, the acritarch assemblage recovered by Lenk et al. (1982), is one that is often associated with, and may be indicative of glacially-stressed marine environments (Lenk et al., 1982; Knoll et al., 1981; Knol1, pers. comm., 1986). There is no evidence of a shelf or shelf-type sediments in the Boston Basin during stages 1 or 2 .

There are several lines of evidence (Vail et al., 1977; Fischer, 1984; and Worsley et al., 1984) which suggest that throughout this episode as we11 as the previous episode of slope/fan deposition and basin evolution, eustatic sea-level was rising throughout the mid-to-late Precambrian and Cambrian in response to tectonic forcing (i.e. changes in ridge volume). Due to the frequent yet periodic appearance of similar facies up or down section within at least the lowermost two-thirds of the Boston Basin succession, we propose that the development of facies patterns during stages 1 and 2 , was largely controlled by the rate of sediment influx into the basin, and not the tectonically driven rise in eustatic sea-level.

We further propose that the rate of sedimentation was largely controlled by climatic changes (the growth and decay of ice) at this time. Vail et al. (1977) have shown that during a relative rise in eustatic sea-leve1 (i.e. late Precambrian to Cambrian), the sedimentation rate determines the geometry of sedimenatry bodies. This results in the production of so-called "transgressive" and "regressive" facies assemblages, even though these assemblages need not be confined to a shelf. It is suggested therefore, that the facies patterns and sedimentary geometry produced in the Boston Basin during stage 1 , and at least part of stage 2 , were likely to have been source controlled. Furthermore, the rate of terrigenous influx to the basin could have been controlled by climate and/or structura1 adjustments during the evolution of the basin. However, structural adjustments are not sediment transport mechanisms, and as such, fall to adequate1y account for the presence of an apparently large volume of coarse detritus. We submit that climate (the presence of ice, for which there is substantial evidence) played a major role in transporting coarse detritus to the basin, and in the development of facies geometry and sedimentary fabric during this period of time.

There is sufficient evidence to suggest that near the termination of stage two, and possibly during the beginning of stage three, the tectonically forced late Precambrian-early Paleozoic rise in eustatic sea-leve1 concelvably began to buffer climate globally (see Worsley et al., 1984; and Fischer, 1984), thereby reducing the effect of climate (the presence of ice) on the sedimentation rate and the competence of flow mechanisms. The net effect of this change was a reduction in clast size and lower rates of sedimentation.

From the standpoint of tectonics, there is reason to believe that the basin was continuing to widen and deepen (therma1 decay of the crust) as sediments were continually being introduced into the basin. Mafic volcanic activity continued in the form of basaltic dikes, sills, and flows which appear to have been hydrothermally altered (Hon and Hepburn, 1986; Durfee-Cardoza, 1985). The flows seem to have been confined to the moderately lower, more channelized parts of the slope to the north (see section 1, Fig. 5). Anderson et al. (1979; 1983), Kurtz and Anderson (1979), and Mial1 (1983; 1985) have reported similar depositional systems on the Antarctic She1f and slope, and for the Gowganda Formation of Canada, respectively.

\section{Stage 3}

During the final episode of basin evolution, ice shelves and icebergs appear to have melted for the last time presumably due to a tectonically forced high stand of eustatic sea-level which ameliorated climate globally during the early Paleozolc. Fischer (1984) and Worsley et al. (1984) have shown that there is a non-random relationship (feedback system) between tectonically controlled fluctuations in eustatic sea-level and major glacial events in the geologic record, at least throughout the late Proterozoic and early Phanerozoic. Reduced sedimentation rates and the absence of ice resulted in the build-up of fine-grained sediment on the slope/fan over an extensive period of time. Much of the previously deposited fine-grained sediment was reworked by bottom currents during this time. Shelf and shelf-type (paralic) deposits such as quartz arenites, and calcareous sandstones and shales with abundant organic matter and shelled organisms appeared for the first time (Fig. 10C).

The shelf deposits are suggested to have been deposited landward of the slope to the southsouthwest and are thought to have extended some distance into the basin on top of the previously deposited prograded and aggraded slope deposits which now acted as a platform for the accumulation of shelf-type deposits. We propose that the shelf deposits then became the shoreward facies equivalent of slope/fan deposits at the margin of the basin. Yet, at the same time, the shelf deposits accumulated unconformably on top of older slope/fan deposits, and the Dedham Granite, Lynn Volcanics, and older crust (landward) without any apparent interruption in sedimentation.

Some confusion exists, however, as to whether these shelf sediments are part of the original basin fill sequence or whether they represent an overlap sequence unrelated to the older sediments which they now overlie. Because these shelf sediments crop out to the south-southwest where shelf deposits associated with this basin would be expected to crop out, they are considered to be a genetic part of the Boston Basin succession. A more complete resolution of the nature of the shelf deposits is linked to resolution of the nature and time of emplacement of Avalon terrane.

\section{DISCUSSION AND CONCLUSIONS}

The depositional model presented here departs in many ways from previous interpretations of the Boston Bay Group, but perhaps one of the most significant points of departure lies in our interpretation of the cross-stratified and 
horizontally stratified diamictites and sandstones (Dms, Dcs, and Ss1 facies) in section 1 (Fig. 5) as probable distal debris flow deposits, highdensity turbidites and conceivably traction deposits which were laid down upon a moderately channelized distal submarine slope/fan. The historic and prevailing, yet largely unsubstantiated interpretation of the Boston Bay Group is that it is part of an alluvial fan/braided stream system (Billings, pers. comm., 1986; Bailey and Galli, 1985; Bailey, 1986; Bailey, pers. comm., 1986). This interpretation is apparently principally based upon the presence of rounded clasts (pebbles and cobbles), channelized contacts, and most important1y, the presence of traction-generated features such as planar and trough cross-stratified diamictites and sandstones generally confined to beds which are less than half a meter in thickness.

We would like to point out, however, that within the last ten years or more our understanding of subaqueous and submarine slope/fan systems and sediment-gravity depositional mechanisms has vast1y improved. Investigations such as those of Winn and Dott (1977), Dott and Bird (1979), Damuth et al. (1983) and Anderson (pers. comm., 1986) have not only documented the presence of large-scale (in excess of 4 to 12 meters in thickness) trough and planar cross-stratified diamictites and sandstones, but have also shown that submarine fan and canyon deposits commonly consist of intricate networks of braided and meandering distributary systems. Were it not for the fact that these braided and meandering networks are associated with a variety of sediment gravity deposits within submarine slope/fan settings, it would be difficult at best to distinguish these deposits from terrestrial counterparts (Hein, 1984). Rounded gravel and cobbles, channelized contacts, and planar and trough cross-stratified diamictites and sandstones do not by themselves preclude the existence of a submarine fan/slope system, nor do they alone confirm the existence of an alluvial fan/braided stream system.

Within the Boston Basin there is a broad spectrum of facles rangting from predominantly poorly sorted diamictites and graded sandstones in the southern part of the basin (sections 3-5), to moderately sorted, stratified diamictites and graded sandstones in the northern part of the basin (section 1). We submit that this change in fabric is systematic, representing a transition from debris flow, turbidite, and possibly traction deposits in the south, to largely turbidite and possibly traction deposits in the north. Furthermore, we would stress that sediment gravity depositional mechanisms such as high density turbidity currents pass through a traction phase of deposition during attenuation, often resulting in the build-up of meters of cobbly, grave11y, and sandy stratified and cross-stratified deposits (Komar, 1970; Winn and Dott, 1977; and Lowe, 1982).

Additionally, the presence of spillitized basaltic andesite flows (Durfee-Cardoza et al., 1984) near the top of section 1 (Fig. 5), and the presence of dropstones in sections 1,3 , and 4 (Fig. 5) suggests that these rocks were deposited below water-level in a glacial marine setting.

Another area of historic debate centers on the question of whether or not the Boston Bay Group records evidence of late Precambrian glaciation.
It is our contention that the Boston Bay Group does record evidence of late Precambrian glactation, and that the evidence lies, in part, in the presence of dropstones, which alone is considered compelling evidence for the presence of ice (Anderson, 1983). and the presence of faceted clasts.

Severa1 additional yet independent lines of evidence, albeit presentiy inferential to various degrees, also point to the presence of ice in the Boston Basin during the late Precambrian. First of a11, a recently established late PrecambrianCambrian age for the Boston Bay Group via radiometric dating of the Mattapan Volcanics (Kaye and Zartman, 1980) and the discovery of Vendian microfossils (Lenk et al., 1982) coincides with a worldwide late Precambrian glaciation (Frakes, 1979). Secondly, the Vendian microfossils discovered in the Boston Basin are dominated by the probable cyanobacterium Bavlinella faveolata which has been found in association with glacigenic deposits elsewhere (Vida1, 1979; Knol1 et al., 1981; and Knoll, 1984). Unfortunately, these microfossils in the Boston Basin remain largely uninvestigated.

Historically, several investigators have also cited the presence of striated clasts (Lahee, 1914; Sayles, 1914; Sayles and LaForge, 1910; 1919) chattermarks on the surfaces of quartz grains (Rehmer and Hepburn, 1974), and dropstones (Cameron, 1979c) in the Roxbury Conglomerate as evidence for glaciation. However, investigators such as Dott (1961) have argued that because striated clasts can be non-glacigenic, their presence does not make a compeling argument for glaciation. We have also found that many clasts are cleaved and show evidence of differential rates of weathering rendering positive identification of "striations" questionable. It should be noted however, that striated clasts are not at all abundant, and in some instances, are absent from Ple1stocene glacigenic deposits and presumably glacigenic deposits in general (Anderson, 1983). Furthermore, many glacial marine sequences in the geologic record are devoid of a striated pavement (Anderson, 1983) as is the case for the Boston Basin.

Bailey (1984; and pers. comm., 1986) has recently argued that what appear to be dropstones in the Boston Basin are instead isolated clasts which rolled or bounced into their present position, or were transported within a debris flow and settled down through the matrix of the debris flow and/or into the underlying surface after the debris flow had come to rest. In either instance, the lonestones are suggested to be non-glacigenic.

We would point out however, that in the former case, it is well established that clasts which move by rolling along the bottom, are aligned with their long axes lying in the plane of the depositional surface, yet transverse to the flow direction (Sneed and Folk, 1958). Furthermore, Lindsay et al. (1970) plotted the orientation of the 1ong axes of apparent dropstones from the "Squantum Tillite" in the vicinity of section 4 (Fig. 5), and found that the clast orientations exhibited an axial fabric in the form of a horizontal girdle (randomly oriented within a plane) suggesting that the lonestone were 1ikely to be dropstones deposited in quiet water, and subsequent1y unmodified by currents. Our field observations reveal that a significant number of dropstones are oriented with 
their intermediate axes, and some with their long axes, perpendicular to bedding planes and projectIng above the bed, draped over by laminated siltstones and sandstones.

In the latter case it can be demonstrated, from the standpoint of flow behavior (Lowe, 1982), that isolated clasts (1onestones) are rarely, if ever, 1ikely to owe their origin to emplacement by debris flows (see Socci and Smith, in press; for a discussion of debris flow mechanics and dropstones).

The mechanisms proposed by Bailey (1984; pers. comm. 1986) to explain the presence of lone clasts in the Boston Basin by means other than having been released from melting ice, are not supported by fleld observations, laboratory studies, or theory. More important1y, these proposed mechanisms cannot account for the disruption of bedding associated with each of these clasts. Dropstone fabrics within the Boston Bay Group reflect the entire spectrum of dropstone fabrics found in Pleistocene subaqueous and submarine glacial deposits (see Thomas and Conne11, 1985; for a review of Recent dropstone fabrics). Furthermore, we maintain that the sum of the evidence cited above formulates a compeling argument for late Precambrian glaciation in the Boston Basin.

\section{ACKNOWLEDGEMENTS}

The authors would like to thank the Ohio University Cartographic Center, and specifica11y. Frank Kenney, Lana Collison, and David G. Glascow for the illustrations. We would also 11ke to thank Harold C. Stephens and Lars Lutton. We are indebted to R. D. Nance, Daniel Murray, Christopher Baldwin, and an anonymous reviewer for reviewing the manuscript and offering many useful criticisms and comments. This work was partially supported by an Ohio University Research Grant and by an Ohio University Baker Award.

ANDERSON, J.B. 1983. Anclent glacial-marine deposits: their spatial and temporal.distribution. . In Glacial-Marine Sedimentation. Edited by B.G. Molnia. Plenum Press, New York, pp. 3-92.

ANDERSON, J.B., BRAKR, C. , DOMACK, E., MYERS, N., and WRIGHT, R. 1983. Development of a Polar Glaclal-Marine Sedimentation Mode1 from Antarctic Quaternary Deposits and Glaclological Information. In Glacial-Marine Sedimentation. Edited by. B.G. Molnia. Plenum Press, New York, pp. 233-264.

ANDERSON, J.B., KURTZ, D.D. . and WEAVER, F.M. 1979. Sedimentation on the Antarctic continental slope. In Geology of Continental Slopes. Edited by L.H. Doyle and O.H. Pilkey. Specia1 Publication Soclety of Economic. Paleontologists and Mineralogists, Tulsa, Oklahoma, 27, pp. 265-283.

BAILEY; R. 1986. Stratigraphy of the Boston Bay Group, Boston area. Geological Soctety of America, Decade of North American Geology. In press.

BAILEY, R.. and GALLI, K.G. 1985. Sedimentary tectonics and sandstone petrogenesis: Boston Basin, Massachusetts. Geological Soclety of America, Abstracts with Programs, 17, p. 3.

BAILEY, R. 1984. Origin of dropstones in the Precambrian Boston Bay Group. Geological Society of America, Abstracts w1th Programs, 16, p. 2.

BAILEY, R., NEWMAN. W.A., and GENES. A. 1976. Geology of the Squantum "T111ite". In Geology of Southeastern New . England. Edited by B. Cameron. New England Intercolleglate Geological Conference, 68th Annual Meeting, pp. 92-106.

BELL. K.G. 1948. Geology of the Boston Metropolitan Area. $\mathrm{Ph} . \mathrm{D}$. dissertation, Massachusetts Institute of Technology. Massachusetts, 390 p.

BILLINGS, M.P. 1929. Structural geology of the eastern part of the Boston Basin. Amertcan Journal of Science, 18, pp. 97137.
BILLINGS, M.P. 1975. Geology of the North Metropolitan Relief Turne1, Greater Boston, Massachusetts. Journal of the Boston Soclety of Civil Rngineers Section, American Society of C1v11 Engineers, 62, pp. 115-135.

BILLINGS, M.P. 1976a. Bedrock Geology of the Boston Basin. In Geology of Southeastern New England. Edited by B. Cameron. New England Intercolleglate Geological Conference, 68th Annual Meeting, pp. 28-45.

BILLINGS, M.P. 1976b. Geology of the Boston Basin. In Studies in New England Geology. Edited by P.C. Lyons and A.H. Brownlow. Geological Society of America, Memoir 146. pp. 530

BILLINGS, M.P. 1979a. Boston Basin, Massachusetts. In The Mississippian and Pennsylvanian (Carboniferous) Systems in the United States - Massachusetts, Rhode Island, and Maine. Edited by J.W. Skehan, S.J.. D.P. Murray, J.C. Hepburn, M.P. Billings, P.C. Lyons and R.o. Doyle. United States Geological Survey, Professional Paper 110-A-L, Part A, pp. A15-A20.

BILLINGS M.P. 1979b. Bedrock Geology of the Boston Basin. In Carboniferous Basins in Southeastern New England. Edited by B. Cameron. Fleld guidebook for Trip No. 5, 9th International Congress of Carboniferous Stratigraphy and Geology. pp. 46-64.

BILLINGS, M.P. and RAHM, D.C. 1966. Geology of the Malden Tunne1. Massachusetts. Journal of Boston Soctety of Civil Engineers, 53, pp. 116-141.

BILLINGS, M.P.. and TIERNEY, C.L. 1964, Geology of the City Tunne1 Extension, Greater Boston, Massachusetts. Journal of Boston Society of Civ1l Engineers, 51. pp. 111-154.

BILLINGS, M.P., LOOMIS, F.B. Jr., and STEWART. 1939. Carboniferous topography in the vicinity of Boston, Massachusetts. Geological Soclety of America Bulletin, 50 . pp. 1867-1884.

BURR, H.T., and BURKE, R.E. 1900. The occurrence of fossils in the Roxbury Conglomerate. Proceedings of the Boston Soclety of Natural History. 29, pp. 179-184.

CALDWELL, D.W. 1964. The Squantum Formation: Paleozolc tillite or tillold? In Guldebook to Field Trips in the Boston Area and Vicinity. Edited by J.W. Skehan, S.J. New England Intercolleglate Geological Conference, 56th Annual Meeting, pp. 53-60.

CAMERON, B. 1979a. General Geology and the Carboniferous Basins of Eastern Massachusetts and Rhode Island. In Carboniferous Basins of Southeastern New England. Edited by B. Cameron. Field guidebook for Trip No. 5, 9th International Congress of Carboniferous Stratigraphy and Geology, pp. 1-6.

CAMERON. B. 1979b. Age of the Boston Basin - A Review of the Problem. In Carbontferous Basins of Southeastern New England. Edited by B. Cameron. Field guldebook for Trip No. 5, 9th International Congress of Carbontferous Strattigraphy and Geology, pp. 65-74.

CAMERON, B. 1979c. Evidence for Glaciation in the Boston Basin. In Carboniferous Basins of Southeastern New England. Edited by B. Cameron. Field guldebook for Trlp No. 5, 9th International Congress of Carbondferous Stratigraphy and Geology, pp. 75-80.

CAMERON, B., and JBANNB, R.A. 1976. New Evidence for Glaciation during deposition of the Boston Bay Group. In Geology of Southeastern New England. Edited by B. Cameron. New England Intercolleglate Geological Conference, 68th Annual Meeting, pp. 117-134.

CAMERON, B., and NAYLOR, R.S. 1976. General Geology of Southeastern New England.: In Geology of Southeastern New England. Edited by B. Cameron. New England Intercolleglate Geological Conference, 68th Annual Meeting, pp. 13-27.

CARTER, R.M. 1975. A discussion and classification of subaqueous mass-transport with particular application to grain-flow, slurry-flow, and fluxoturbidites. Earth-Sctence Revlew, 11, pp. 145-177.

CROSBY, W.0. 1900. Geology of the Boston Basin: The Blue Hills. Boston Society of Natural History, Occasional Paper, 4, pp. 289-563.

DAMUTH, J.E., KOLLA, K., FLOOD, R.D. , KOWSMANN, R.O. , MONIEIRO, M.C., GORINI, M.A., PALMA, J.J.C., and BELDERSON, R.H. 1983 Distributary channe1 meandering and bifurcation patterns on the Amazon deep sea fan as revealed by long-range side-scan sonar (GLORIA). Geology, 11, pp. 94-98.

DODGE, W.W. 1883. Notes on the geology of eastern Massachusetts. - Boston Society of Natural H1story, 21, pp. 197-216.

DOTT, R.H. 1961. Squantum "T1111te", Massachusetts-Evidence of glaciation or subsqueous mass movements? Geological Society of America Bulletin, 72, pp. 1289-1306.

DOTT, R.H. , and BIRD, K.J. 1979. Sand transport through channels across an Eccene shelf and slope in southwestern Oregon. In Geology of Continental Slopes. Edited by L.J. Doyle, and

0.H. Plikey Jr. Special Publication Soclety of Economic 
Paleontologists and Mineralogists, Tulsa, Oklahoma, 27, pp. 327-342.

DURFEE-CARDOZA, K. . HON, R., and HEPBURN, J.C. 1985. Petrology and geochemistry of the Precambrian intermediate and mafic volcanic rocks of the Boston platform, eastern Massachusetts. Geological Soclety of America. Abstracts with Programs, 17. pp. 16-17.

EMERSON, B.K. 1917. Geology of Massachusetts and Rhode Island. United States Geological Survey Bulletin, 597, pp. 56-57.

ENOS, P. 1977. Flow regimes in debris flow. Sedimentology. 24, pp, 133-142.

EYLES, N., EYLES, C.H., and MIALL, A.D. 1983. Lithofacies types and vertical profile models; an alternative approach to the description and environnental interpretation of glacial diamict sequences. Sedimentology, 30, pp. 393-410.

FISCHER, A.G. 1984. The two Phanerozoic supercycles. In Catastrophes in Earth History, The New Uniformitarlanism. Edited by W.A. Berggren, and J.A. Van Couvering. Princeton University Press, Lawrenceville, New Jersey, pp. 129-150.

FRAKES, L.A. 1979. Climates Throughout Geologic Time. Elsevier, New York, pp. 57-96.

HAMPTON, M.A. 1979. Buoyancy in debrls flows. Journal of Sedimentary Petrology, 49, pp. 753-758.

HAMPTON, M.A. 1975. Competence of fine-grained debris flows. Journal of Sedimentary Petrology, 45, pp. 834-844.

HAMPTON, M.A. 1972. The role of subaqueous debris flow in generating turbidity currents. Journal of Sedimentary Petrology, 42, pp. 775-793.

HEIN, F.J. 1984. Deep-sea and fluvial braided channe1 conglomerates: a comparison of two case studies. In Sedimentology of Grave1s and Conglomerates. Edited by E.H. Koster, and R.J. Steel. Canadian Society of Petroleun Geologists, Memolr 10, pp. 33-49.

HITCHCOCK, E. 1861. On the conversion of certain conglomerates into talcose and micaceous schlsts and gnelsses, by the elongation. flattening, and metamorphosis of the pebbles and the cement. American Journal of Sclence, 31, pp. 372-392.

HOBBS, W.B. 1899. Some new fossils from eastern Massachusetts. American Geology, 23, pp. 109-115.

HON, R. , and HEPBURN, J.C. 1986. Igneous geochemistry and its implication for terrane analysis of the Avalonian event in southeastern New England, U.S.A. Atlantic Geoscience Society Abstract, 1986 Colloguium, Maritime Sediments and Atlantic Geology, 22, p. 331.

KAYE, C.A. 1984. Boston Basin Restudied. In Geology of the Coasta1 Lowlands, Boston, Massachusetts to Kennebunk, Malne. Edited by L.S. Hanson. 76th Annual New England Intercolleglate Geological Conference, Salem, Massachusetts, pp. 124140.

KAYE, C.A., and ZARTMAN, R.E. 1980. A late Proterozolc $Z$ to Cambrian age for the stratified rocks of the Boston Basin. In Proceedings "The Caledonides in the U.S.A." I.C.G.P. Project, 27, Caledontan Orogen. Edited by D.R. Wones. Virginia Polytechnic Institute and State University, Memolr 2. pp. 257-262.

KNOLL, A.H., BLICK, N., and AWRAMIK, S.M. 1981. Stratigraphic and ecologic 1mp1ications of late Precambrian microfossils from Utah. American Journal of Science, 281, pp. 247-263.

KNOLL, A.H. 1984. Microblotas of the late Precambrian Hunnberg Formation, Nordaustlandet, Svalbard. Paleontology. 58, pp. $131-162$.

KOMAR, P.D. 1970. The competence of turbidity current flow. Geological Society of America Bulletin, 81. pp. 1555-1562.

KURTZ, D.D., and ANDERSON, J.B. 1979. Recognition and sedimentologlc description of recent debris flow deposits from the Ross and Wedde11 Seas, Antarctica. Journal of Sedimentary Petrology, 49, pp. 1159-1170.

LAFORGE, L. 1932. Geology of the Boston area, Massachusetts. United States Geological Survey Bulletin, 839, 105 p.

LAHEE, F.H. 1914. Late Paleozolc glaciation in the Boston Basin, Massachusetts. American Journal of Science, 187, pp 316-318.

LENK, C. , STROTHER, P.K. , KAYE, C.A., and BARGHOORN, E.S. 1982. Precambrian age of the Boston basin: new evidence fron microfoss1ls. Sctence, 216, pp. $619-620$.

LINDSAY, J.F., SUMMERSON, C.H., and BARRETT, P.J. 1970 . A long-axis clast fabric compartson of the Squantum "Tillite", Massachusetts and the Gowganda Formation, Ontario. Journal of Sedimentary Petrology, 40, pp. 475-479.

LOWE, D.R. 1982. Sediment gravity flows: II. Depositional models with special reference to the deposits of high-density turbidity currents. Journal of Sedimentary Petrology, 52, pp. 270-297.

LOWE, D.R. 1979. Sediment gravity flows: thetr classification and some problems of application to natural flows and deposits. In Geology of Continental Slopes. Edited by I.H. Doyle, and 0.H. Pilkey. Special Publication Society of
Economic Paleontologists and Mineralogists, Tulsa, Oklahoma, 27. pp. $75-82$.

LOWE, D.R. 1976a. Grain flow and grain flow deposits. Journal of Sedimentary Petrology, 46, pp. 188-199.

LOWE, D.R. 1976b. Subaqueous ilquified and fluidized sediment flows and their deposits. Sedimentology, 23. pp. 285-308.

MANSFIELD, G.R. 1906. The origin and structure of the Roxbury Conglomerate. Harvard Museum Comparative Zoology Bulletin. 49, pp. 90-271.

MIALL, A.H. 1985. Sedimentation on an early Proterozoic continental margin under glacial influence: The Gowganda Formation (Huronian), E111ot Lake area, Ontario, Canada. Sedimentology, 32, pp. 763-788.

MIALL, A.H. 1983. Glaciomarine sedimentation in the Gowganda Formation (Huronian), northern Ontario. Journal of Sedimentary Petrology, 53, pp. 477-491.

MIALL, A.H. 1978. Lithofacies types and vertical profile models in braided rivers: a summary. In Fluvial Sedimentology. Edited by A.H. Mall. Canadian Soclety of Petroleum Geologists, Memoir 5, pp. 597-604.

MIALL, A.H. 1977. A review of the bralded river depositional environment. Earth-Science Review, 13, pp. 1-62.

MIDDLETON, G.V., and HAMPTON, M.A. 1976. Subaqueous sediment transport and deposition by sediment gravity flow. In Marine Sediment Transport and Environmental Management. Edited by D.J. Stanley, and D.J.P. Swift. Wlley, New York, pp. 197-218. MIDDLETON, G.V., and HAMPTON, M.A. 1973. Sediment gravity flows: mechanies of flow and deposition, Part 1 . In Turbidites and Deep-Water Sedimentation. Chairpersons G.V. Middleton, and A.H. Bouma. Society of Economic Paleontologists and Mineralogists, Short Course, Anaheim. California, pp. 1-38.

NARDIN, T.R. HEIN, F.J., GORSLINE, D.S., and EDWARDS, B.D. 1979. A review of mass movement processes, sediment and acoustic characteristics, and contrasts in slope and base-ofslope systems versus canyon-fan-basin floor systems. In Geology of Continental Slopes. Edited by L.J. Doyle, and 0.H. Pilkey. Special Publication Society of Economic Paleontologists and Mineralogists, Tulsa, Oklahoma, 27, pp. 61-73.

NAYLOR, R.S., and SAYER, S. 1976. The Blue Hills igneous complex, Boston area, Massachusetts. In Geology of Southeastern New England. Edited by B. Cameron. New England Intercollegiate Geological Conference, 68th Annual Meeting. pp. $135-146$.

NELSON, C.H. and NILSEN, T.H. 1984. Modern and Anctent DeepSea Fan Sedimentation. Society of Economic Paleontologists and Mineralogists, Short Course, 14, Tulsa, Oklahoma, $404 \mathrm{p}$.

POLLARD. M. 1965. Age, origin and structure of the postCambrian Boston strata, Massachusetts. Geological Society of America Bullet1n, 76, pp. 1065-1068.

RAHM, D.A. 1962. Geology of the Main Drainage Tunne1, Boston, Massachusetts. Journal of Boston Soctety Civil Engineers, 49 pp. 319-368.

RAST, N., and SKEHAN, J.W., S.J. 1983. The evolution of the Avalonian plate. Tectonophysics, 100, pp. 257-286.

REHMER, J. 1981. The Squantum tilloid member of the Roxbury Conglomerate of Boston, Massachusetts. In Earth's PrePlelstocene Glaclal Record. Edited by M.J. Hambrey, and W.B. Harland. Cambridge University Press, London, pp. 756-759.

REHMER, J.A., and HEPBURN, J.C. 1974. Quartz sand surface textural evidence for a glacial origin of the Squantum "Til11te", Boston Basin, Massachusetts. Geology, 2, pp. 413415.

REHMER, J.A., and ROY, D.C. 1976. The Boston Bay Group: the boulder problem. In Geology of Southeastern New England. Edited by B. Cameron. New England Intercollegiate Geological Conference, 68th Annual Meeting, pp. 71-91.

RICHARDSON, S.M. 1975. Geology of the Dorchester Tunnel. Metropolitan District, Boston, Massachusetts, 44 p.

RODINE, J.D., and JOHNSON, A.M. 1976. The ability of debris heavily freighted with coarse clastic materlals, to flow on gentle slopes. Sedimentology, 23, pp. 213-234.

SAYLES, R.W. 1914. The Squantum Tilitte. Harvard Museum of Comparative Zoology Bulletin, Geological Serles 10, 56, pp. 141-175.

SAYLES, R.W. , and LAFORGE, L. 1910. The glacial origin of the Roxbury Conglomerate. Sclence, New Serles, 32, pp. 723-724.

SAYLES, R.W. , and LAFORGE, L. 1919. Seasonal deposition in aqueo-glacial sediments. Harvard Museum of Comparative Zoology, Memotr 47, pp. 1-67.

SHALER, N.S. 1871. On the relations of the rocks in the vicinity of Boston. Boston Soclety of Natural History, 13. pp. $172-177$

SKEHAN, J.W., S.J. 1983. Geological profiles through the Avalon terrain of southeastern Massachusetts, Rhode Island, and eastern Connecticut, U.S.A. In Profiles of Orogenic Belts. Edited by N. Rast, and F.M. Delany. Geodynamics 
Series, 10, American Geophysical Union, Washington, D.C., pp. 275-300.

SKEHAN, J.H., S.J. 1979. Puddingstone, Drumlins, and Ancient Volcanoes. Wes Stone Press, Dedham, MA, pp. X-XVII.

SKEHAN, J.W., S.J. and MURRAY, D.P. 1980a. A model for the evolution of the eastern margin of the northern Appalachians. In Proceedings "The Caledonides in the U.S.A.". Edited by D.R. Wones. I.G.C.P. Project 27: Caledonian Orogen, Virginia Polytechnic Institute and State University, Memo1r 2, pp. 6772.

SKEHAN, J.W., S.J. and MURRAY, D.P. 1980b. Geologic profile across southeastern New England. Tectonophysics, 69, pp. 285319.

SMITH, G.W. and SOCCI. A.D. In Review. Late Precambrian diamictites of the Boston Basin, Massachusetts. Geological Society of America Bulletin.

SMITH, G.W. and SOCCI, A.D. 1986. Late Precambrian diamictites of the Boston Basin, Massachusetts. Geological Society of America, Abstracts with Programs, 18, p. 66.

SNEED, E.D. and FOLK, R.L. 1958. Pebbles in the lower Colorado River, Texas, a study in particle morphogenesis. Journal of Geology, 66, pp. 14-150.

SOCCI. A.D. 1984. A hypothesis for the evolution of suspect Avaion-type sedimentary and metasedimentary rocks of the Boston Basin and the northern Appalachians. Society of Economic Paleontologists and Mineralogists, 1st . Annual Meeting, San Jose, California, p. 77.

SOCCI, A.D., 1985. Late Precambrian Avalon-type sedimentary rocks of the Boston Basin: A probable glacial-marine fan complex. Geological Society of America, Abstracts with Programs, 17, p. 64

SOCCI, A.D. and SMITH, G.W. 1985. Sedimentology and climatic Impilcations of the Avalon-type tectono-stratigraphic succession in the Boston Basin. Geological Association of CanadaMineralogical Association of Canada Jo1nt Annual Meeting. Abstracts with Programs. Fredericton, New Brunswick, p. A58.

SOCCI, A.D. and SMITH, G.W. 1986a. Recent developments in the sedimentology and stratigraphy of the Avalon of New England The Boston Basin. Atlantic Geoscience Society Abstract, Arherst, Nova Scotia. Maritime Sediments and Atlantic Geolgoy, 22, pp. 205-206.

SOCCI, A.D. and SMITH, G.W. 1986b. Stratigraphy and sedimentology of the late Precambrian Boston Bay Group, Boston. Massachusetts. Geological Society of America, Abstracts with Programs, 18 , p. 67.

SOCCI. A.D. and SMITH, G.W. 1986c. Depositional history of late Precambrian sedimentary rocks in the Boston Basin. Boston, Massachusetts: A preliminary model. Geological
Society of America, Abstracts with Programs, 18, p. 67.

SOCCI, A.D. and SMITH, G.W. In Review. Evidence for late Proterozolc glaciation in the Boston Basin succession, Boston, Massachusetts. Geology.

THOMAS, G.S.P., and CONNELL, R. J. 1985. Iceberg drop, dump, and grounding structures from Pleistocene glacio-1acustrine sediments. Journal of Sedimentary Petrolog 55 pp. 243-249. TIERNEY, L.F., BILLINGS, M.P., and CASSIDY, M.M. 1968. Geology of the City Tunnel Extension, Greater Boston, Massachusetts. Journal of Boston Society of C1vi1 Engineers, 55, pp. 60-96.

VAIL, P.R. MITCHUM, R.M. J J., and THOMPSON, S., III, 1977. Selsmic stratigraphy and global changes of sea level, part 3: Relative changes of sea level from coastal onlap. In Seismic Stratigraphy - Applications to Hydrocarbon Exploration. Edited by C.E. Payton. American Association of Petroleum Geologists, Memoir 26, pp. 63-82.

VIDAL G. 1979. Acritarchs from the Upper Proterozo1c and Lower Cambrian of East Sweden. Gronlands Geologiske Undersoge1se Bulletin, p. 134.

VISHER, G.S. 1965. Use of the vertical profile in environmental reconstruction. American Association of Petroleum Geologists Bulletin, 49, pp. 41-61.

WALKER, R.G. 1975. Generalized factes models for resedimented conglomerates of turbidite association. Geological Soclety of America Bulletin, 86, pp. 737-748.

HALKER, R.G. 1984. Turbidites and Associated Coarse Clastic Deposits. In Facies Mode1s. Edited by R.G. Walker. Geological Association of Canada, Geoscience Canada, Reprint Series 1, pp. $171-188$.

WINN, R.D., Jr. and DOTT, R.H., Jr. 1977. Large-scale traction-produced structures in deep-water fan-channe1 conglomerates in southern Chile. Geology, 5, pp. 41-44.

WOLFE, C.W. 1976. Geology of Squaw Head, Squantum, Massachusetts. In Geology of Southeastern New England. Edited by B. Cameron. New England Intercolleglate Geological Conference, 68th Annual Meet1ng, pp. 106-116.

WORSTEY T.R. NANCE, R.D. and MOODY, J.B. 1984. Global tectonics and eustasy for the past 2 billion years. Marine Geology, 58, pp. 373-400.

WRIGHT, R. and ANDERSON, J.B. 1982. The importance of sediment gravity flow to sediment transport and sorting in a glacial marine environment: Eastern Wedde11 Sea, Antarctica. Geological Society of America Bullet1n, 93, pp. 951-963.

ZARTMAN, R.E. and NAYLOR, R.S. 1984. Structural Implications of some radiometric ages of igneous rocks in southeastern New England. Geological Society of America Bulletin, 95, pp. 522539. 